\title{
Predicting the distribution of threatened orbicellid corals in shallow and mesophotic reef ecosystems
}

\author{
Katharine E. Egan ${ }^{1,2,3,5, *}$, T. Shay Viehman ${ }^{2}$, Daniel M. Holstein ${ }^{4}$, Matthew Poti ${ }^{2,3}$, \\ Sarah H. Groves ${ }^{2,3}$, Tyler B. Smith ${ }^{1}$ \\ ${ }^{1}$ Center for Marine and Environmental Studies, University of the Virgin Islands, St. Thomas, USVI 00802, USA \\ ${ }^{2}$ National Centers for Coastal Ocean Science, Marine Spatial Ecology Division, \\ National Oceanic and Atmospheric Administration, Beaufort, NC 28516, and Silver Spring, MD 20910, USA \\ ${ }^{3}$ CSS, Inc., Fairfax, VA 22030, USA \\ ${ }^{4}$ Department of Oceanography and Coastal Sciences, College of the Coast and Environment, Louisiana State University, \\ Baton Rouge, LA 70803, USA \\ ${ }^{5}$ Present address: Office of Ocean Exploration and Research, National Oceanic and Atmospheric Administration, \\ Silver Spring, MD 20910, USA
}

\begin{abstract}
Orbicellid corals are threatened primary reef-building corals throughout the Caribbean in shallow and mesophotic coral ecosystems (MCEs), yet a poor understanding of where they occur limits population monitoring and management. The goals of this study were to predict suitable habitat for orbicellid coral species and to identify how abiotic environmental factors constrain that habitat on the eastern Puerto Rico Shelf. The probability of occurrence for Orbicella annularis and O. faveolata/O. franksi (combined) from shallow to mesophotic depths on the eastern Puerto Rico Shelf was predicted using maximum entropy models. Contributions of abiotic predictors, including bathymetry, seafloor topography, temperature, wave exposure, and bottom velocity, were assessed. Model performance was assessed using area under the receiver operating characteristic curve, standard error of the replicate model runs, and mean absolute error. Both O. annularis and O. faveolata/O. franksi distributions were best predicted by rugosity, temperature, and wave exposure. O. faveolata/O. franksi occurred at shallow and mesophotic depths, and acted as a proxy for identifying the spatial extent of MCEs, contrary to O. annularis, which was predicted at shallow depths. Results for O. faveolata/O. franksi in mesophotic depths indicated potential for large areas of unexplored and unmonitored MCEs along the southeast shelf of St. Thomas, US Virgin Islands and within the Virgin Passage. These spatial predictions of potential mesophotic reef habitats will provide direction for future MCE exploration efforts.
\end{abstract}

KEY WORDS: Orbicella spp. $\cdot$ Species distribution modeling $\cdot$ Maximum entropy $\cdot$ Mesophotic coral ecosystems $\cdot$ Threatened species

\section{INTRODUCTION}

Caribbean coral reef-building is dominated by 2 genera, Acropora and Orbicella. These reef-building corals face multiple threats, including coastal development, land-based pollution, and climate change (Pandolfi et al. 2003). The branching acroporid corals have seen extreme population loss since the 1970s

*Corresponding author: katharine.egan@noaa.gov
(Aronson \& Precht 2001), leaving 3 massive orbicellid species $(O$. annularis, $O$. faveolata, and $O$. franksi) as the foundational species. However, orbicellid populations have also declined throughout the Caribbean (Jackson et al. 2014, Edmunds 2015), and their recent precipitous decline has led to all 3 species being classified as 'threatened' under the United States Endangered Species Act (79 FR 53852, 10 September 2014).

(C) D. M. Holstein, T. B. Smith and, outside the USA, the US Government, 2021. Open Access under Creative Commons by Attribution Licence. Use, distribution and reproduction are unrestricted. Authors and original publication must be credited. 
Orbicellids are primary reef-building corals (Goreau \& Wells 1967, Reed 1985, Weil \& Knowlton 1994) in shallow and mesophotic coral ecosystems (MCEs), which are found globally between 30 and $150 \mathrm{~m}$ depths. O. annularis primarily occupies shallow reef habitat (Pandolfi \& Budd 2008) in depths less than $20 \mathrm{~m}$ (Weil \& Knowlton 1994), whereas $O$. faveolata and $O$. franksi are common in depths up to $60 \mathrm{~m}$ throughout the Caribbean (Armstrong et al. 2006, Menza et al. 2008, Smith et al. 2008, 2010). In the United States Virgin Islands (USVI), mesophotic orbicellid banks are the dominant overall coral reef type, with cover and density surpassing shallow coral reef development (Smith et al. 2019). High cover orbicellid mesophotic reefs are primarily found along the southern insular shelf of the northern USVI (St. Thomas and St. John; Smith et al. 2010; see Fig. 1) and extend along the southern shelf of Puerto Rico. Mesophotic depths also extend out along the northern shelf area of St. Thomas, but these areas have sparse orbicellid and total coral cover (Groves 2016). Orbicellids are strongly structured by wave exposure and tend to form reefs in sheltered locations (Done 1983, Chollett \& Mumby 2012). Due to their depth, mesophotic reefs are protected from strong wave action and provide this ideal sheltered habitat (Lesser et al. 2009), although Smith et al. (2016a) suggest that upper MCEs are also structured by storms. Other abiotic characteristics are associated with the structure of hardbottom mesophotic habitats including seafloor complexity as measured by metrics like rugosity and slope (Sheppard 1982, Sherman et al. 2010), temperature (Lesser et al. 2018), and light (Kahng et al. 2019, Tamir et al. 2019). However, it is unknown if these characteristics are correlated with other factors that contribute to coral development.

Given the importance of Orbicella spp. in the Caribbean, mapping their distribution in shallow and mesophotic depths is critical to guide effective management of dwindling populations. Characterization of MCEs is limited due to the logistical constraints of diver-based and remote observations at mesophotic depths (Hinderstein et al. 2010). In some areas of the Caribbean, there have been recent improvements in classifying well-developed mesophotic shelf areas (e.g. the insular shelf of the northern USVI; Costa et al. 2017), but the resulting maps were not designed to show the distribution of specific coral species, such as orbicellids.

Species distribution modeling (SDM) is a quantitative approach to predict the potential habitat of an organism across a landscape or seascape based on the abiotic variables that shape its distribution (Guisan \& Zimmermann 2000, Franklin \& Miller 2009). SDMs have been utilized to predict the distributions of threatened and endangered species (Godown \& Peterson 2000, Engler et al. 2004), and can be used for monitoring declining populations, implementing restoration plans, managing and conserving critical habitat, or identifying unknown populations (Guisan et al. 2013). They have been applied to deep and shallow coral reef habitats (see Bridge et al. 2012, Chollett \& Mumby 2012, Franklin et al. 2013, Georgian et al. 2014, Costa et al. 2015, Silva \& MacDonald 2017). SDMs are also used to explore how abiotic factors influence species' distributions through variable contribution (i.e. how much does the abiotic variable contribute to the predicted distributions), and SDMs can be used to explore how variable contribution changes with different model spatial scales (resolution and extent) (Van Horn 2002).

Here we present a predictive species distribution modeling effort for orbicellid corals on the eastern Puerto Rico Shelf from shallow to mesophotic depths. The study objectives were to (1) develop SDMs for the threatened coral species $O$. annularis and $O$. faveolata/O. franksi (combined) using coral presence records and abiotic variables associated with orbicellid distributions to identify mesophotic coral habitat, (2) assess whether abiotic variable contributions vary within shallow and mesophotic depths or by geographic region (northeast and southeast shores), and (3) provide spatial predictive maps to help guide characterizations of potential mesophotic reef habitat for future field validation.

\section{MATERIALS AND METHODS}

\subsection{Study area}

St. Thomas and St. John, USVI, are located on the eastern Puerto Rico Shelf at the interface of the northeastern Caribbean Sea and tropical western Atlantic. The shelf area also consists of the main island of Puerto Rico, Culebra, Vieques, and the British Virgin Islands. The shelf area encompassing the northern USVI (up to $65 \mathrm{~m}$ depth) is $1572 \mathrm{~km}^{2}$ (Kadison et al. 2017). The study area included shallow to mesophotic depths (extending to $60 \mathrm{~m}$ ) surrounding the islands of St. Thomas and St. John, USVI, and Culebra and Vieques, Puerto Rico (Fig. 1). 


\subsection{Study species}

Orbicella spp. occurrence data were compiled from multiple shallow and mesophotic reef survey efforts conducted from 2007 to 2017. These datasets included (1) spatially stratified random drop camera and diver surveys characterizing the mesophotic depths of the north and south shores of St. Thomas (Smith et al. 2010, 2016a, Groves 2016; depth >30 m); (2) permanent transects from the USVI Territorial Coral Reef Monitoring Program (Smith et al. 2015; 5-40 m); (3) the National Oceanic and Atmospheric Administration (NOAA) National Coral Reef Monitoring Program (NCRMP; NCCOS 2016, NCCOS \& SEFSC 2018; 1-33 m) based on a stratified random design framework targeting hardbottom habitat; and (4) benthic habitat mapping for the southeast shelf of St. Thomas and St. John by the NOAA National Centers for Coastal Ocean Science (Costa et al. 2017; 30-100 m). These datasets used to extract Orbicella spp. occurrence data are heterogeneous in nature, and there are discrepancies in the area or spatial scale covered for each survey. For example, NCRMP sampling uses a $50 \mathrm{~m}$ grid to target survey locations, and only sample once per grid cell. However, $15 \mathrm{~m}$ transects are conducted per grid cell. The other surveys mentioned here employ similar methods and cover smaller areas within each $50 \mathrm{~m}$ grid cell so the presences used in the model reflect where Orbicella spp. are generally abundant. See Text S1 in the Supplement at www.int-res.com/articles/suppl/m667 p061_supp.pdf for a description of the survey design for each dataset.

Occurrences of $O$. annularis, $O$. faveolata, and $O$. franksi were extracted from all surveys. $O$. faveolata and $O$. franksi occurrences were combined (i.e. 1 or both species present at a survey location) because they are difficult to distinguish at deeper depths (Herzlieb et al. 2006), occupy the same niche, and may hybridize (Szmant et al. 1997). Species occurrences outside the spatial extent of the predictor datasets were not included, and each cell (at a $50 \mathrm{~m}$ resolution)

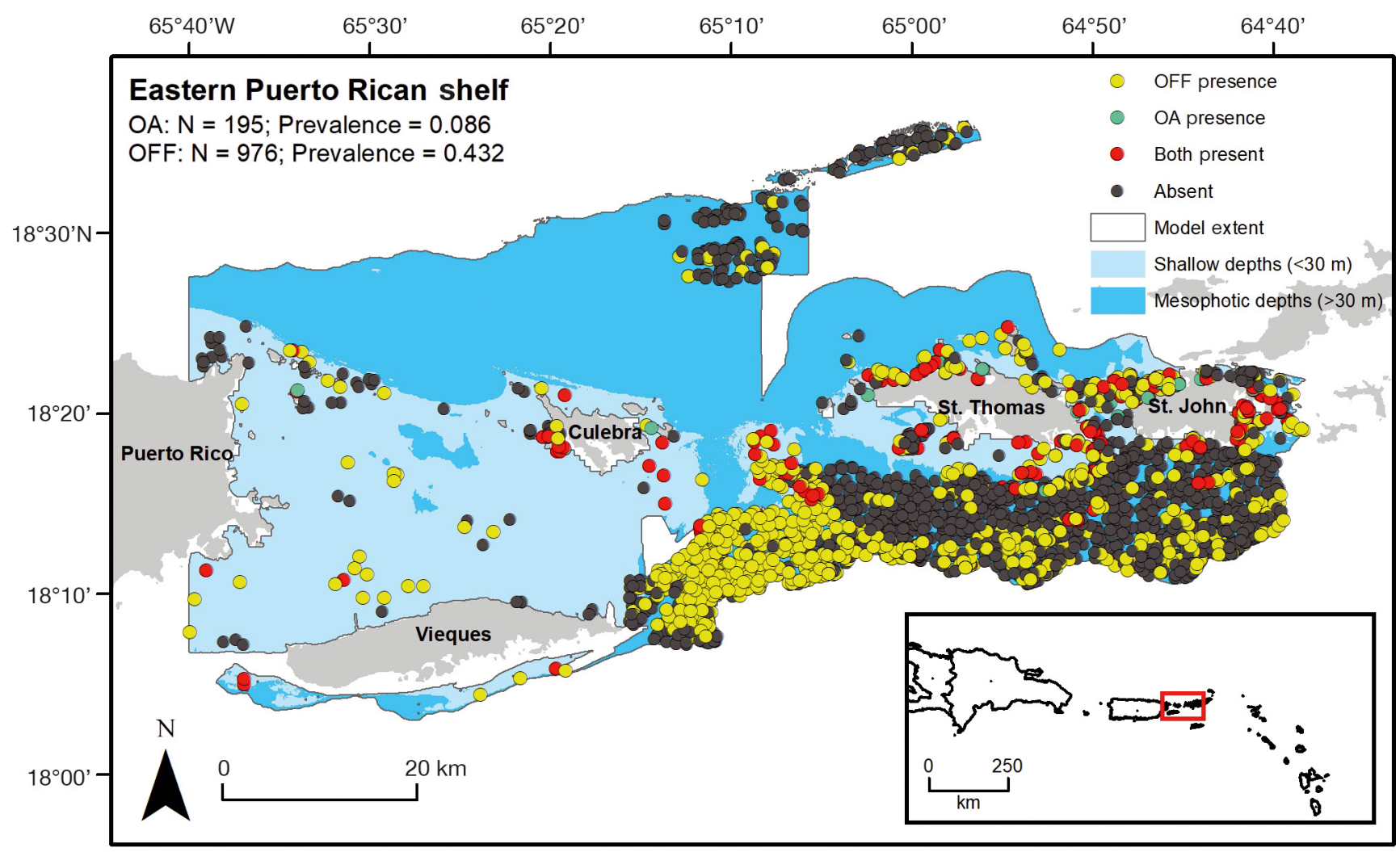

Fig. 1. Study site on the eastern Puerto Rico Shelf encompassing St. Thomas and St. John (US Virgin Islands) and Culebra and Vieques (Puerto Rico). The extent of the model is represented in the grey outline, with shallow and mesophotic depths shown. The presence of Orbicella annularis (OA), O. faveolata/O. franksi (OFF), both Orbicella spp., and absences are displayed in addition to the number of presences and calculated prevalence for each coral group. Some areas of the study area have straight edges due to the size of some of the grids of the predictors. In particular, the regional ocean modeling system (ROMS) grid (bottom velocity), was square shaped and encompassed a large part of the area. The bathymetry layer was then clipped to the ROMS layer 
within the predictive framework was limited to a single occurrence (i.e. duplicate occurrences in each grid cell were removed) to reduce potential sampling biases for the model. For each coral group, prevalence was also calculated (number of presences / total number of presence and absence points combined) (see Figs. $1 \& 2$ ) to be used as a parameter in the models based on modeling methods conducted by Costa et al. (2015). Using prevalence as a parameter in the models is further explained in Section 2.5.1. We tested the spatial autocorrelation of the presence points and found that they were spatially autocorrelated, which can bias model results (Dormann et al. 2007). However, after thinning the presence points, we found that we had an insufficient number of presence points to create accurate models. We discuss the limitations of spatially autocorrelated data in Section 4.2. Data compilation and cleaning were conducted in R software v. 3.3.3 (R Core Team 2017). Spatial autocorrelation analyses were conducted using the 'Spatial Analyst' toolbox in ArcGIS v. 10.5.1.

\subsection{Abiotic variables}

Abiotic variables tested during model development included bathymetry (depth), seafloor complexity, sea surface temperature (SST), benthic orbital velocity, wave height, wave period, wave direction, and bottom velocity (Table 1 ). The extent of the study area was limited to $60 \mathrm{~m}$ depth to account for known depth limitations of Orbicella spp. (Smith et al. 2010). The extent of the study area was also limited by the available coverage of high-resolution bathymetry data and the extent of the bottom velocity data. All abiotic variables were resampled to a $50 \mathrm{~m}$ resolution. We modeled at a $50 \mathrm{~m}$ resolution to account for variability in GPS data and to match the resolution of the sampling grid used for the NOAA NCMRP data collection.

For the study area, bathymetry was mosaicked from multibeam sonar and light detection and ranging (LiDAR) data collected from 2008 to 2016 by NOAA (retrieved from https://www.ncei.noaa.gov/). The native spatial resolution of the bathymetry data ranged from 2 to $10 \mathrm{~m}$, but we developed bathymetric variables at a resolution of $50 \mathrm{~m}$. Seafloor complexity variables derived from bathymetry included aspect, standard deviation of the depth, rugosity, slope, change in slope, total curvature, planform curvature, and profile curvature at a $50 \mathrm{~m}$ resolution. Rugosity was calculated as the ratio of the surface area to the planar area across the neighborhood of a central pixel, derived from the compiled bathymetry data. Using this method, flat areas are equal to 1 , with more rugose areas $>1$ (Jenness 2004, Wilson et al. 2007); this is closer to a measurement of relief rather than the rugosity produced by individual coral colonies. Bathymetric derivations were conducted using the 'Spatial Analyst' toolbox in ArcGIS v. 10.5.1, and the rugosity was derived using DEM Surface Tools (Jenness 2004, 2013).

We used the National Aeronautics and Space Administration Multi-Scale Ultra-High Resolution Sea Surface Temperature data (NASA MUR; https://podaac. jpl.nasa.gov/MEaSUREs-MUR). Daily daytime SSTs were provided at $1 \mathrm{~km}$ resolution for 2011-2017. Average, maximum, minimum, range, and summer average (June-September) temperatures were first calculated from the native $1 \mathrm{~km}$ resolution SST grids across the temporal range of the data. The resulting grids were then resampled to $50 \mathrm{~m}$ resolution using bilinear interpolation and clipped to the model extent.

Wave height, wave period, and wave direction were acquired from the Caribbean Coastal Ocean Observing System (CariCOOS; https://www.caricoos. org/data-download) using the CariCOOS Nearshore Wave Model (Anselmi-Molina et al. 2012, Canals et al. 2012) and a Simulating Waves Nearshore spectral wave model (Booij et al. 1999) made twice daily from 2013 to 2016 at a $200 \mathrm{~m}$ native resolution. The average and maximum wave height and period (along with average wave direction) were calculated from the $200 \mathrm{~m}$ native resolution grids, and then resampled to a $50 \mathrm{~m}$ resolution using bilinear interpolation. The average and maximum benthic orbital velocities were also calculated across all grids (using the equation of Wiberg \& Sherwood 2008). Bottom velocity was acquired from Regional Ocean Modeling System (ROMS) simulations based on in situ current measurements throughout the water column (see Cherubin et al. 2011). It was included to represent currents at depth driven by oceanographic variables other than surface waves. The ROMS model had a temporal range from 2007 to 2008 and native resolution of $330 \mathrm{~m}$, and was resampled to a $50 \mathrm{~m}$ resolution using bilinear interpretation.

\subsection{Model extents}

Within our model domain, there is variability in environmental conditions between regions and depths (Fig. 1). Environmental conditions differ between the northeast and southeast shores of this area (Groves 2016, Groves et al. 2018) as well as between shallow and mesophotic depths (Smith et al. 2016a). To identify how orbicellid distributions are influenced by 
Table 1. Descriptions of abiotic variables (environmental predictors) that were used to develop the MaxEnt models for Orbicella annularis and O. faveolata/O. franksi. SST: sea surface temperature; CariCOOS: Caribbean Coastal Ocean Observing System. Wave direction units are in radians, but for ease of interpretation, are displayed as degrees throughout the paper. NA: temporal and/or native resolution are not applicable to the predictor

\begin{tabular}{|c|c|c|c|c|}
\hline Predictor & Unit & $\begin{array}{l}\text { Temporal } \\
\text { resolution }\end{array}$ & $\begin{array}{l}\text { Native } \\
\text { resolution }\end{array}$ & Definition \\
\hline Depth (mean) & $\mathrm{m}$ & NA & $\begin{array}{l}2-10 \mathrm{~m} \\
\text { (resampled } \\
\text { to } 50 \mathrm{~m} \text { ) }\end{array}$ & Water depth (to seafloor) \\
\hline Depth (SD) & $\mathrm{m}$ & NA & NA & $\begin{array}{l}\text { Dispersion of water depth around the mean calculated } \\
\text { using the ArcGIS 'Focal Statistics' tool by deriving the } \\
\text { compiled bathymetry data at } 50 \mathrm{~m}\end{array}$ \\
\hline Aspect & $\circ$ & NA & NA & $\begin{array}{l}\text { Compass direction of maximum slope calculated } \\
\text { the ArcGIS 'Aspect' tool by deriving the compiled using } \\
\text { bathymetry data at } 50 \mathrm{~m}\end{array}$ \\
\hline Curvature & $\begin{array}{l}1 / 100 \mathrm{~cm} ; \\
\text { concave }(-) \\
\text { convex }(+)\end{array}$ & NA & NA & $\begin{array}{l}\text { Measure of convexity/concavity of the landscape } \\
\text { calculated using the ArcGIS 'Curvature' tool by deriving } \\
\text { the compiled bathymetry data at } 50 \mathrm{~m}\end{array}$ \\
\hline $\begin{array}{l}\text { Planform } \\
\text { curvature }\end{array}$ & $\begin{array}{l}1 / 100 \mathrm{~cm} ; \\
\text { concave }(-) \\
\text { convex }(+)\end{array}$ & NA & NA & $\begin{array}{l}\text { Curvature of the surface perpendicular to the maximum } \\
\text { slope direction calculated using the ArcGIS 'Curvature' tool } \\
\text { by deriving the compiled bathymetry data at } 50 \mathrm{~m}\end{array}$ \\
\hline Profile curvature & $\begin{array}{l}1 / 100 \mathrm{~cm} ; \\
\text { concave }(-) \\
\text { convex }(+)\end{array}$ & NA & NA & $\begin{array}{l}\text { Curvature of the surface parallel to the maximum slope } \\
\text { direction calculated using the ArcGIS 'Curvature' tool } \\
\text { by deriving the compiled bathymetry data at } 50 \mathrm{~m}\end{array}$ \\
\hline Rugosity & Unitless & NA & NA & $\begin{array}{l}\text { Ratio of surface area to planar area calculated using } \\
\text { DEM Surface Tools (Jenness 2013) by deriving the compiled } \\
\text { bathymetry data } 50 \mathrm{~m}\end{array}$ \\
\hline Slope & $\circ$ & NA & NA & $\begin{array}{l}\text { Angle of the seafloor calculated using the ArcGIS 'Slope' tool } \\
\text { by deriving the compiled bathymetry data at } 50 \mathrm{~m}\end{array}$ \\
\hline Change in slope & $\begin{array}{l}\text { Degrees of } \\
\text { degrees }\end{array}$ & NA & NA & $\begin{array}{l}\text { Maximum rate of change in slope calculated using the } \\
\text { ArcGIS 'Slope' tool be deriving the slope data at } 50 \mathrm{~m}\end{array}$ \\
\hline SST (mean) & ${ }^{\circ} \mathrm{C}$ & $2011-2017$ & $\begin{array}{l}0.01^{\circ} ;(1.11 \mathrm{~km} ; \\
\text { resampled } \\
\text { to } 50 \mathrm{~m})\end{array}$ & Average temperature of the sea surface during the day \\
\hline SST (minimum) & ${ }^{\circ} \mathrm{C}$ & $2011-2017$ & $\begin{array}{c}0.01^{\circ} ;(1.11 \mathrm{~km} ; \\
\text { resampled } \\
\text { to } 50 \mathrm{~m})\end{array}$ & $\begin{array}{l}\text { Minimum temperature over } 2011-2017 \text { of the sea surface } \\
\text { during the day }\end{array}$ \\
\hline SST (maximum) & ${ }^{\circ} \mathrm{C}$ & $2011-2017$ & $\begin{array}{l}0.01^{\circ} ;(1.11 \mathrm{~km} ; \\
\text { resamples } \\
\text { to } 50 \mathrm{~m})\end{array}$ & $\begin{array}{l}\text { Maximum temperature over 2011-2017 of the sea surface } \\
\text { during the day }\end{array}$ \\
\hline SST (summer mean) & ${ }^{\circ} \mathrm{C}$ & $2011-2017$ & $\begin{array}{l}0.01^{\circ} ;(1.11 \mathrm{~km} ; \\
\text { resampled } \\
\text { to } 50 \mathrm{~m})\end{array}$ & $\begin{array}{l}\text { Summer (June-September) mean temperature over } \\
2011-2017 \text { of the sea surface during the day }\end{array}$ \\
\hline SST (range) & ${ }^{\circ} \mathrm{C}$ & 2011-2017 & $\begin{array}{l}0.01^{\circ} ;(1.11 \mathrm{~km} ; \\
\text { resampled } \\
\text { to } 50 \mathrm{~m})\end{array}$ & $\begin{array}{l}\text { Minimum temperature subtracted from the maximum of the } \\
\text { sea surface during the day }\end{array}$ \\
\hline Wave height (mean) & $\mathrm{m}$ & 2013-2016 & $\begin{array}{c}200 \mathrm{~m} \\
\text { (resampled } \\
\text { to } 50 \mathrm{~m} \text { ) }\end{array}$ & $\begin{array}{l}\text { Average of the difference between the elevations of a wave } \\
\text { crest and a neighboring trough }\end{array}$ \\
\hline
\end{tabular}


Table 1. Continued

\begin{tabular}{|c|c|c|c|c|}
\hline Abiotic variable & Unit & $\begin{array}{l}\text { Temporal } \\
\text { resolution }\end{array}$ & $\begin{array}{l}\text { Native } \\
\text { resolution }\end{array}$ & Definition \\
\hline $\begin{array}{l}\text { Wave height } \\
\text { (maximum) }\end{array}$ & $\mathrm{m}$ & $2013-2016$ & $\begin{array}{l}200 \mathrm{~m} \\
\text { (resampled } \\
\text { to } 50 \mathrm{~m} \text { ) }\end{array}$ & $\begin{array}{l}\text { Maximum difference between the elevations of a wave cres } \\
\text { and a neighboring trough }\end{array}$ \\
\hline Wave period (mean) & $\mathrm{s}$ & 2013-2016 & $\begin{array}{l}200 \mathrm{~m} \\
\text { (resampled } \\
\text { to } 50 \mathrm{~m} \text { ) }\end{array}$ & Average time it takes the wave cycle to be completed \\
\hline $\begin{array}{l}\text { Wave period } \\
\text { (maximum) }\end{array}$ & $\mathrm{s}$ & $2013-2016$ & $\begin{array}{l}200 \mathrm{~m} \\
\text { (resampled } \\
\text { to } 50 \mathrm{~m} \text { ) }\end{array}$ & Maximum time it takes the wave cycle to be completed over \\
\hline Wave direction & Radians & $2013-2016$ & $\begin{array}{l}200 \mathrm{~m} \\
\text { (resampled } \\
\text { to } 50 \mathrm{~m} \text { ) }\end{array}$ & Direction in which the wave is moving over \\
\hline $\begin{array}{l}\text { Orbital velocity } \\
\text { (mean) }\end{array}$ & $\mathrm{m} \mathrm{s}^{-1}$ & $2013-2016$ & $\begin{array}{l}200 \mathrm{~m} \\
\text { (resampled } \\
\text { to } 50 \mathrm{~m} \text { ) }\end{array}$ & $\begin{array}{l}\text { Average orbital motion within the water column due } \\
\text { to surface-generated waves to a depth equal to half the } \\
\text { wavelength of the wave (Wiberg \& Sherwood 2008) }\end{array}$ \\
\hline $\begin{array}{l}\text { Orbital velocity } \\
\text { (maximum) }\end{array}$ & $\mathrm{m} \mathrm{s}^{-1}$ & $2013-2016$ & $\begin{array}{l}200 \mathrm{~m} \\
\text { (resampled } \\
\text { to } 50 \mathrm{~m} \text { ) }\end{array}$ & $\begin{array}{l}\text { Maximum orbital motion within the water column due } \\
\text { to surface-generated waves to a depth equal to half the } \\
\text { wavelength of the wave a circle (Wiberg \& Sherwood 2008) }\end{array}$ \\
\hline Bottom velocity & $\mathrm{m} \mathrm{s}^{-1}$ & $\begin{array}{l}\text { Derived from in } \\
\text { situ measurements } \\
\text { made in } 2007 \text { and } 2008\end{array}$ & $\begin{array}{l}330 \mathrm{~m} \\
\text { (resampled } \\
\text { to } 50 \mathrm{~m} \text { ) }\end{array}$ & $\begin{array}{l}\text { Resultant vector of the modeled vertical and horizontal } \\
\text { currents at depth (Cherubin et al. 2011) }\end{array}$ \\
\hline
\end{tabular}

variations in the environmental variables at different spatial scales, we compared model predictions for 4 different geographic extents: (1) the primary 0-60 m model, which encompasses shallow and mesophotic depths along the northeast and southeast shores of the Puerto Rico Shelf (referred to as '0-60 m model') (see Figs. 1 \& 2); (2) south shore only (referred to as '0-60 m south shore model'); (3) shallow areas only (0-30 m depth limit; referred to as 'shallow only model'); and (4) mesophotic areas only (30-60 m depth limit: referred to as 'mesophotic only model') (Fig. 2). We removed the north shore of our study area because mesophotic coral development is sparse in this region (Groves 2016), and we hypothesized that the spatial predictions for Orbicella spp. and contributing environmental variables driving those predictions would change with the removal of this area. Additionally, the southeast shore of the study region contains highly developed and dense mesophotic reefs (Smith et al. 2010, 2016b). We wanted to ensure that we were producing model results for the southeast shore region that were as accurate as possible and would not be biased by lack of mesophotic reef development along the northeast shore. Similarly, we modeled at shallow depths and at mesophotic depths separately so those models would not be biased by including the full depth range. $O$. annularis was not included in the mesophotic only model due to a low number of presences in the area. All abiotic variables were clipped to these 4 extents for modeling input, and all Orbicella spp. occurrence data that fell outside these extents were not included in the models.

\subsection{Predicting orbicellid distributions}

Maximum entropy modeling (MaxEnt v. 3.4.0; Phillips et al. 2017) was used to create spatially explicit predictions of $O$. annularis and O. faveolata/O. franksi distributions. MaxEnt is a presence/background sample SDM (sometimes referred to as presenceonly) that predicts habitat suitability based on correlation between species presences and environmental conditions and extends this correlation to other areas with similar conditions (Phillips et al. 2006, 2017). Maximum entropy modeling is a common method for estimating species distributions from presence data when absence records are unavailable or unreliable (Elith et al. 2011, Merow et al. 2013), and is commonly implemented using the Java software MaxEnt 

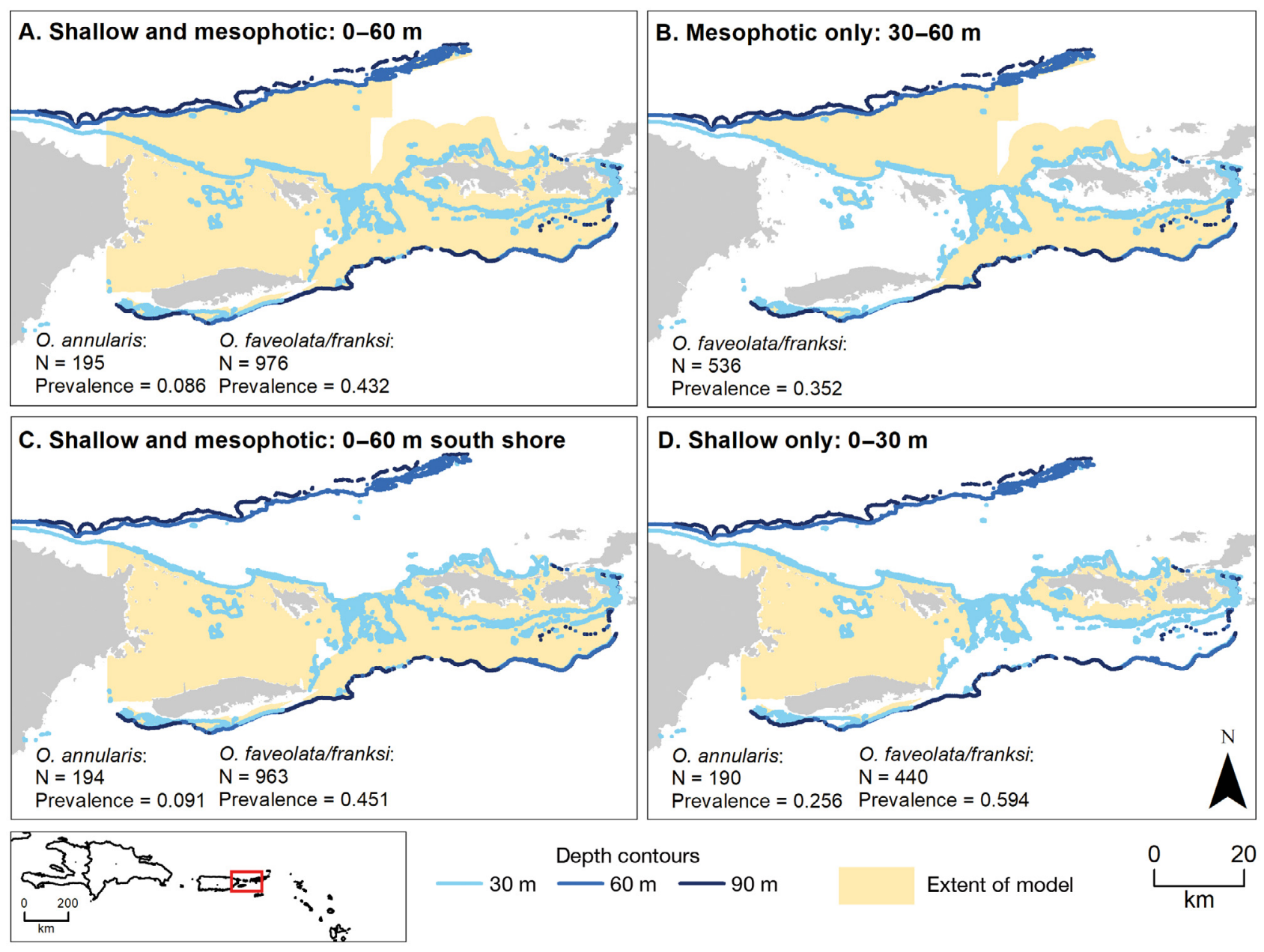

Fig. 2. Extents of the 4 different models: (A) shallow and mesophotic depths (0-60 m), (B) mesophotic only (30-60 m), (C) shallow and mesophotic $(0-60 \mathrm{~m})$, but with the north shore mesophotic areas removed, and (D) shallow only (0-30 m). Also displayed are the 30,60, and $90 \mathrm{~m}$ depth contours. Number of presences and prevalence for each coral group based on the model extent are listed. Orbicella annularis was not modeled for the mesophotic only model due to the lack of presences at those depths

(Phillips et al. 2006, 2017). MaxEnt uses a statistical machine learning algorithm to estimate the distribution (geographic range constrained by the extent of the environmental predictors) of a species by finding the distribution which has maximum entropy (Phillips et al. 2006, 2017). The MaxEnt formulation is used to maximize the likelihood of a parametric exponential distribution (Phillips et al. 2004), and is mathematically equivalent to a Poisson point process model (Renner \& Warton 2013). We chose to use MaxEnt because it is a common modeling technique for predicting the distribution of deep-water corals (Georgian et al. 2014, Kinlan et al. 2020) and mesophotic corals (Costa et al. 2015, Silva \& MacDonald 2017). We also chose to use MaxEnt due to the abundance of presences for Orbicella spp. at mesophotic depths along the south shore, making it difficult to use other modeling methods. Because we were look- ing for areas of undiscovered mesophotic reef in this section of the Caribbean using Orbicella spp. as a proxy, we determined that MaxEnt models would be the best in identifying unsampled areas with the highest likelihood of finding orbicellids.

\subsubsection{Model development}

We developed our modeling methods by following the advice outlined by Merow et al. (2013) and the mesophotic modeling methods of Costa et al. (2015). Model development, performance, and evaluation were based on 10 replicate MaxEnt models for each coral group (O. annularis and $O$. faveolata/O. franksi). The parameters that were set in the MaxEnt models were as follows: random seed $=$ on, replicated run type $=$ subsample, replicates $=10$, maximum iterations 
$=500$, and number of background samples $=10000$. The random seed refers to the randomly chosen starting point used to subset the data for model training and cross validation. The regularization value (or beta multiplier) is a MaxEnt parameter used in machine learning to reduce overfitting of the model. The regularization value was determined using the 'MaxentVariableSelection' package in R v. 3.3.3 (Jueterbock et al. 2016), which runs preliminary MaxEnt models and tests a series of beta multipliers. The beta multipliers tested in the preliminary model runs included $\beta=1,2,3,5,7,11$, and 13 , and were tested for each of the 4 comparative models. The regularization value that yielded a minimum small-scale adjusted Akaike's information criterion (AICC) (Burnham \& Anderson 2002) for each model can be found in Table $\mathrm{S} 1$ in the Supplement. We also ran preliminary models testing a different number of background samples (5000, 10000 , and 20000 ), and found that 10000 background samples yielded the smallest AICc.

Of the 22 predictors, 8 created the best models for both coral groups. Images of the 8 predictors can be found in Fig. S1 in the Supplement. We used a pairwise correlation analysis to reduce the number of predictors. We removed highly correlated predictors, and ran a series of preliminary MaxEnt models testing different combinations of predictors that created the best model based on the AICC and the area under the receiver operating characteristic (ROC) curve (i.e. area under the curve; AUC). We also chose predictors that were most ecologically relevant in driving Orbicella spp. distributions. The default prevalence calculated for each coral group based on the presence and absence data was 0.086 for $O$. annularis and 0.432 for O. faveolata/O. franksi for the 0-60 m model; however, the prevalence differed with changes in the spatial extent of the models (see Fig. 2 for the other prevalence calculations), and was included as a parameter in the MaxEnt models. An inherent issue with presence/background modeling (e.g. MaxEnt) is that prevalence cannot be calculated from presence-only datasets. The prevalence parameter in MaxEnt models is arbitrarily set to 0.5 by default (Elith et al. 2011). Prevalence in this case is a measure of the sampling effort. It can be used for a more accurate interpretation of the logistic transformed spatial predicted outputs, and allows for a direct comparison between the coral groups that are modeled. The prevalence parameter used in these models is only estimated within the study area and does not represent prevalence throughout the entire distribution of a species (Elith et al. 2011). With a priori organism prevalence data, MaxEnt can be applied to specifically predict the probability of species occurrence rather than the habitat suitability (e.g. Elith et al. 2011, Costa et al. 2015). Data were randomly partitioned so that $70 \%$ of records were used for training and calibrating the model, and $30 \%$ were used to test model performance. For each replicate model run, different portions of the data were randomly subset for training and testing.

The resulting spatial predictive maps from MaxEnt depicted the complementary log-log (cloglog) transformed output, which represents the probability of occurrence on a scale of 0 to $100 \%$, where $100 \%$ demonstrates that there is a $100 \%$ probability of the species occurring within that specified grid cell. The cloglog transformation gives a more appropriate estimate of the probability of species occurrence compared to the previous default output of MaxEnt, the logistic transformation (Phillips et al. 2017). The maximum training sensitivity plus specificity threshold (max SSS) calculated from the MaxEnt models was applied to the resulting continuous spatial predictions to create binary spatial predictive maps, which were used to identify the area the species is likely to occupy (Liu et al. 2013, 2016).

\subsubsection{Model performance}

The discrimination capacities (the ability of the model to correctly distinguish between presences and background samples) of all models were assessed using ROC curves, which compare the sensitivity (true positive prediction rate) to 1 - the specificity (false positive prediction rate) over the range of predicted values. The AUC is the measure of the model's performance. AUC of 0.5 is indicative of the null model, meaning the model is no better at discriminating between presences and background points than random chance. Models with an AUC greater than 0.9 indicate superior model performance (Hosmer et al. 2013). ROC curves with test and training AUC values were generated by MaxEnt for each of the 10 model replicates and averaged.

Model performance was also assessed using reliability, the agreement between predicted and observed values (Liu et al. 2009). Reliability was represented by mean absolute error (MAE), a measurement of the average magnitude of the predictive errors. MAE is defined as:

$$
\operatorname{MAE}=\frac{\sum_{i=1}^{n}\left|y_{i}-x_{i}\right|}{n}
$$

where $n$ is the total number of species presences and true absences, $y_{i}$ is the predicted probability of 
occurrence per grid cell (ranging in values from 0 to 1$)$, and $x_{i}$ is the observed species occurrence $(0$ or 1) based on a method used by Costa et al. (2015). The absence data were thinned similarly to the presence data, where 1 absence was recorded per grid cell to account for sampling biases. If a presence and an absence fell within the same grid cell, that cell was counted as a presence. The occurrences used to calculate MAE were the test presence points $(30 \%$ of the data) set aside by MaxEnt for each of the 10-replicate model runs. The true absence data available for the full modeling region were used (not the background points generated by MaxEnt). The resulting MAE values were averaged across the 10-replicate model runs. A high MAE value is indicative of disagreement between the observed and predicted values. MAE was also calculated individually for both presence and absence values to identify which records were causing the disagreement. MAE calculations were conducted using R software v. 3.3.3 (R Core Team 2017).

\subsubsection{Model uncertainty}

Model uncertainty was quantified to provide some indication of how sampling variability and model structure may have influenced the predicted distributions (Barry \& Elith 2006, Lobo et al. 2008, Elith \& Leathwick 2009). Uncertainty maps for the model replicates of each coral group were created by taking the standard error among the 10 replicate cloglog spatial distribution maps, and were assessed visually for areas of high uncertainty.

\subsubsection{Contribution of predictor variables and response curves}

Contributions of predictor variables to species distribution predictions were measured using the percent contribution of each predictor as calculated by MaxEnt. When the MaxEnt model is trained, it records which environmental variables make the greatest contributions to the model's predictions and converts these into a percentage. Percent contribution of variables was assessed across the 4 different model extents to identify how the abiotic variable contribution changed with depth or geographic region. Response curves were used to assess how probability of occurrence predictions changed in the context of the environmental variables.

\section{RESULTS}

\subsection{Spatial predictions of occurrence}

According to the average test AUC values, both the Orbicella annularis (mean \pm SE: $0.955 \pm 0.002$ ) and $O$. faveolata/O. franksi $(0.873 \pm 0.002)$ models exceeded the random model prediction (AUC > 0.5). O. annularis had a higher probability of occurrence in shallow depths $(<15 \mathrm{~m})$ in the full depth range model (0-60 m; Fig. 3A), whereas O. faveolata/O. franksi occurred more widely in both shallow and mesophotic depths (Fig. 4A). O. faveolata/O. franksi had the highest probability of occurrence in the Virgin Passage, which is an area of reef habitat between the islands of St. Thomas, USVI, and Culebra, Puerto Rico. The max SSS threshold identified more potential habitat area on the southeast shelf compared to the northeast shelf (Fig. 4B). Based on the max SSS threshold area calculations, $O$. annularis was likely present in $474 \mathrm{~km}^{2}\left(13.6 \%\right.$ of the $3497 \mathrm{~km}^{2}$ total survey area), and O. faveolata/O. franksi was likely present in $604 \mathrm{~km}^{2}$ (17.3\% of the total survey area) (Table 2). Modeling results for the other model extents can be found in 'Model extent analyses' and Table S2, both in the Supplement.

\subsection{Spatial prediction uncertainty and error}

The MAE results and uncertainty maps demonstrated greater discrepancies between test presences/ true absences and predicted probabilities for $O$. faveolata/O. franksi. Model uncertainty was high based on visual assessments of the model uncertainty maps (Figs. 3C \& 4C), indicating high variability between the model runs. Based on visual assessments, the highest uncertainties for each coral group were co-located with the highest probability of occurrence values: in the Virgin Passage and along portions of the southern insular shelf for O. faveolata/O. franksi (Fig. 3C), and in shallow areas for O. annularis (Fig. 4C).

The total MAE indicated disagreement between observed and predicted values for O. faveolata/O. franksi, but there was more agreement for $O$. annularis. The MAE $\pm \mathrm{SE}$ was $14.97 \pm 0.54$ and $36.24 \pm$ $0.55 \%$ for $O$. annularis and O. faveolata/O. franksi, respectively. For O. faveolata/O. franksi, both true absences and test presences disagreed with observed predictions when the MAE was calculated separately. This indicated that the models overpredicted in areas where known absences occurred, and underpredicted in areas where test presences were 


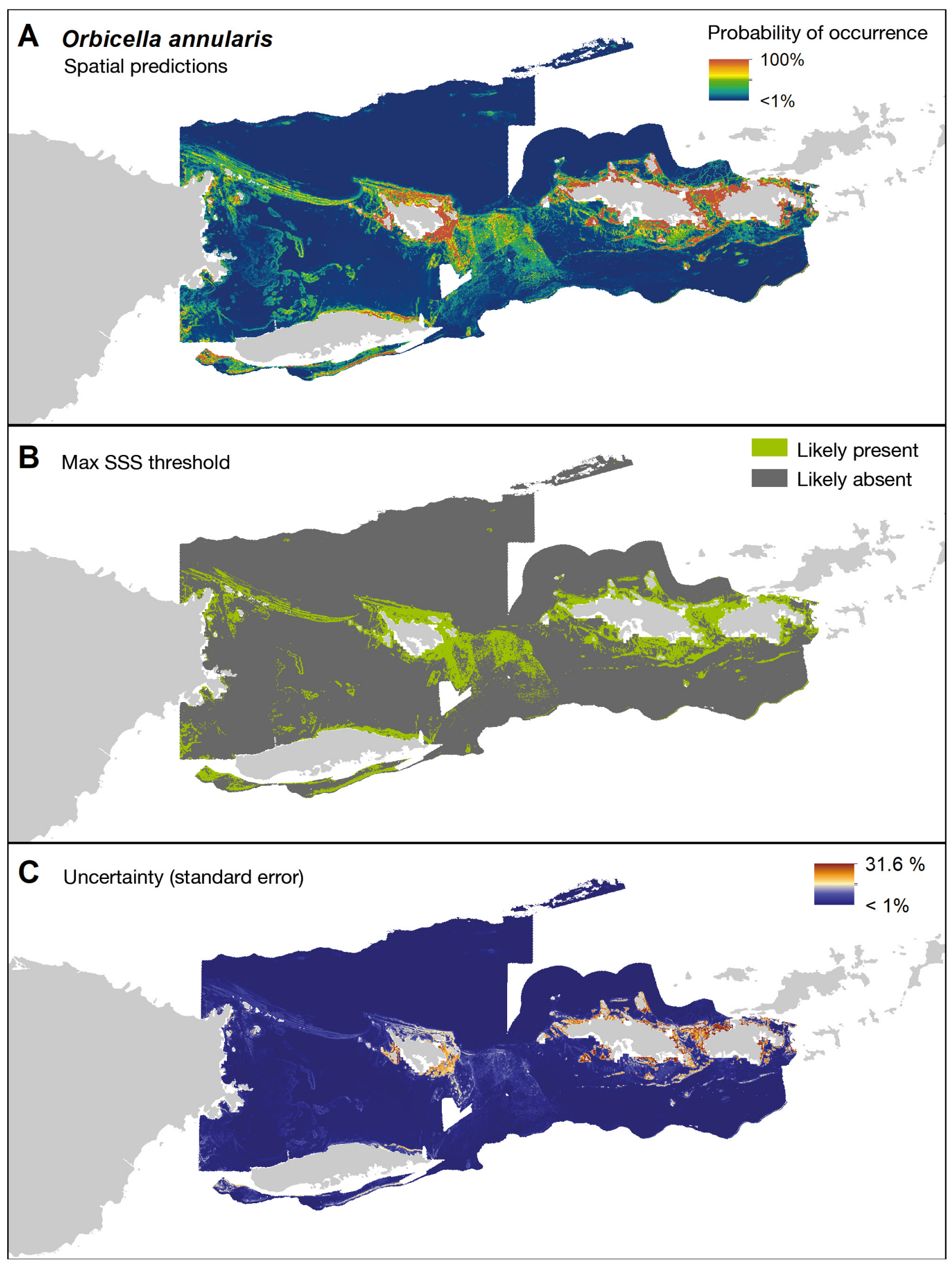

Fig. 3. (A) Spatial predictions for Orbicella annularis encompassing shallow and mesophotic depths for the northeast and southeast shores. Warm-colored areas show high probability of occurrence, while cold-colored areas show low probability of occurrence. (B) Binary map created when applying the maximum training sensitivity plus specificity (max SSS) threshold to the continuous spatial predictions, showing areas of likely presence of $O$. annularis and areas of likely absence. (C) Uncertainty (standard error) associated with the probability of occurrence spatial prediction maps 


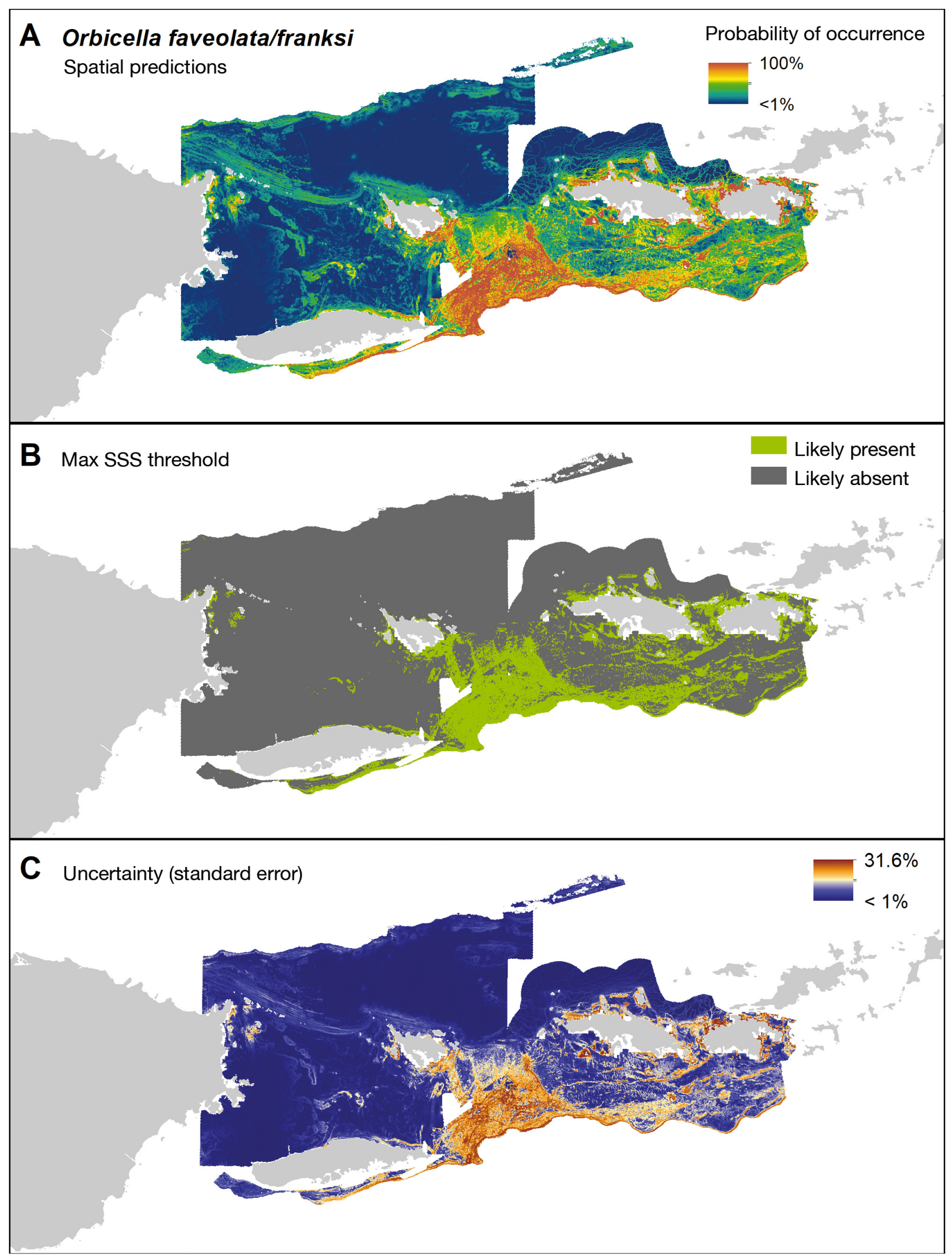

Fig. 4. As in Fig. 3, but for Orbicella faveolata/O. franksi 
Table 2. Threshold calculations. The area represents each coral group likely being present based on the maximum training sensitivity plus specificity threshold (max SSS). The percent of the total area where each coral group is likely present was also calculated (present area / total area $\times 100$ ). OA: Orbicella annularis; OFF: O. faveolata/O. franksi. O. annularis was not modeled for the mesophotic only model due to the lack of presences at those depths

\begin{tabular}{|c|c|c|c|c|c|}
\hline \multirow[t]{2}{*}{ Model type } & \multirow{2}{*}{$\begin{array}{l}\text { Total area } \\
\quad\left(\mathrm{km}^{2}\right)\end{array}$} & \multicolumn{2}{|l|}{$\mathrm{OA}$} & \multicolumn{2}{|c|}{$\mathrm{OFF}$} \\
\hline & & Area $\left(\mathrm{km}^{2}\right)$ & $\%$ & Area $\left(\mathrm{km}^{2}\right)$ & $\%$ \\
\hline $0-60 \mathrm{~m}$ & 3496.66 & 474.45 & 13.57 & 604.34 & 17.28 \\
\hline 0-60 m south shore & 2285.80 & 218.71 & 9.57 & 600.21 & 26.26 \\
\hline Shallow only & 1498.89 & 249.07 & 16.62 & 241.98 & 16.14 \\
\hline Mesophotic only & 2004.75 & - & - & 451.03 & 22.50 \\
\hline
\end{tabular}

variables, with rugosity, depth, and SST range remaining the top 3 predictors for the $0-60 \mathrm{~m}$, south shore and shallow only models (Fig. 5). The rugosity response curves for $O$. annularis indicated that probability of occurrence increased with increasing rugosity (Fig. 7). The probability of occurrence tapered off when a rugosity value of 1 was surpassed. Rugosity values $>1$ are indicative of high-relief habitat, with 1 representing flatter areas. The variation in rugosity no longer mattered in predicting probability of

located. The absence MAE for $O$. annularis suggested disagreement, also signifying either overprediction of $O$. annularis or incorrect absence records (Table 3). MAE results for the other model extents can be found in 'Model extent analyses' and Table S3, both in the Supplement

\subsection{Predictor importance and contribution}

O. annularis and O. faveolata/O. franksi models had similarities in regards to predictor contribution, with some notable differences. For the full model extent, rugosity was the strongest predictor for both $O$. annularis (53.21\%; Fig. 5) and O. faveolata/O. franksi $(65.17 \%$; Fig. 6). Depth (32.96\%) and SST range $(6.01 \%)$ both followed rugosity as important contributors to $O$. annularis predictions. Orbital velocity $(14.24 \%)$ and average SST $(8.70 \%)$ followed rugosity as contributing variables for O. faveolata/O. franksi.

\subsubsection{Orbicella annularis}

Varying spatial extents of abiotic predictors along the eastern Puerto Rico Shelf did not affect predictions of $O$. annularis. The comparative models showed little change in percent contribution of all

Table 3. Number of occurrences and the mean absolute error (MAE) calculations for Orbicella annularis and O. faveolata/O. franksi

\begin{tabular}{|c|c|c|c|c|}
\hline \multirow{2}{*}{ MAE type } & \multicolumn{2}{|c|}{ O. annularis } & \multicolumn{2}{|c|}{ O. faveolata/franksi } \\
\hline & $\mathrm{N}$ & $\mathrm{MAE} \pm \mathrm{SE}(\%)$ & $\mathrm{N}$ & $\mathrm{MAE} \pm \mathrm{SE}(\%)$ \\
\hline Absences & 2076 & $13.57 \pm 0.54$ & 1297 & $38.69 \pm 0.77$ \\
\hline Test presences & 178 & $31.31 \pm 2.42$ & 938 & $32.84 \pm 0.79$ \\
\hline $\begin{array}{l}\text { Absences and } \\
\text { test presences }\end{array}$ & 2254 & $14.97 \pm 0.54$ & 2235 & $36.24 \pm 0.56$ \\
\hline
\end{tabular}

\subsubsection{Orbicella faveolata/O. franksi}

In contrast to $O$. annularis, the variables that best predicted occurrence of $O$. faveolata/O. franksi changed with the extent of the model. The mesophotic only model for O. faveolata/O. franksi was markedly different from the other models. For the 3 models that included shallow water extents $(0-60 \mathrm{~m}$ full, 0-60 m south shore, and shallow only), rugosity was by far the most important variable. In the mesophotic model (30-60 m), wave direction became the most important variable, followed by rugosity and average SST (Fig. 6). The contribution of the second and third most important variables in the models that included shallow water were minor relative to rugosity, but varied slightly between models. Rugosity, wave direction, average SST were the most important predictors in the 0-60 m full model. Rugosity, orbital velocity, and average SST were the 3 predictors contributing most to the probability of occurrence in the 0-60 $\mathrm{m}$ south shore model. Lastly, rugosity, orbital velocity, and SST range were the top 3 contributing variables in the shallow only model.

As with $O$. annularis, the response curves indicated an increase in rugosity above a value of 1 , which was associated with increased probability of occurrence for O. faveolata/O. franksi (Fig. 7). The response curves for wave direction showed a strong shift from low probability at $45^{\circ}$ to a peak in probability between 80 and $110^{\circ}$ for O. faveolata/O. franksi. Average SST showed a consistent high probability 


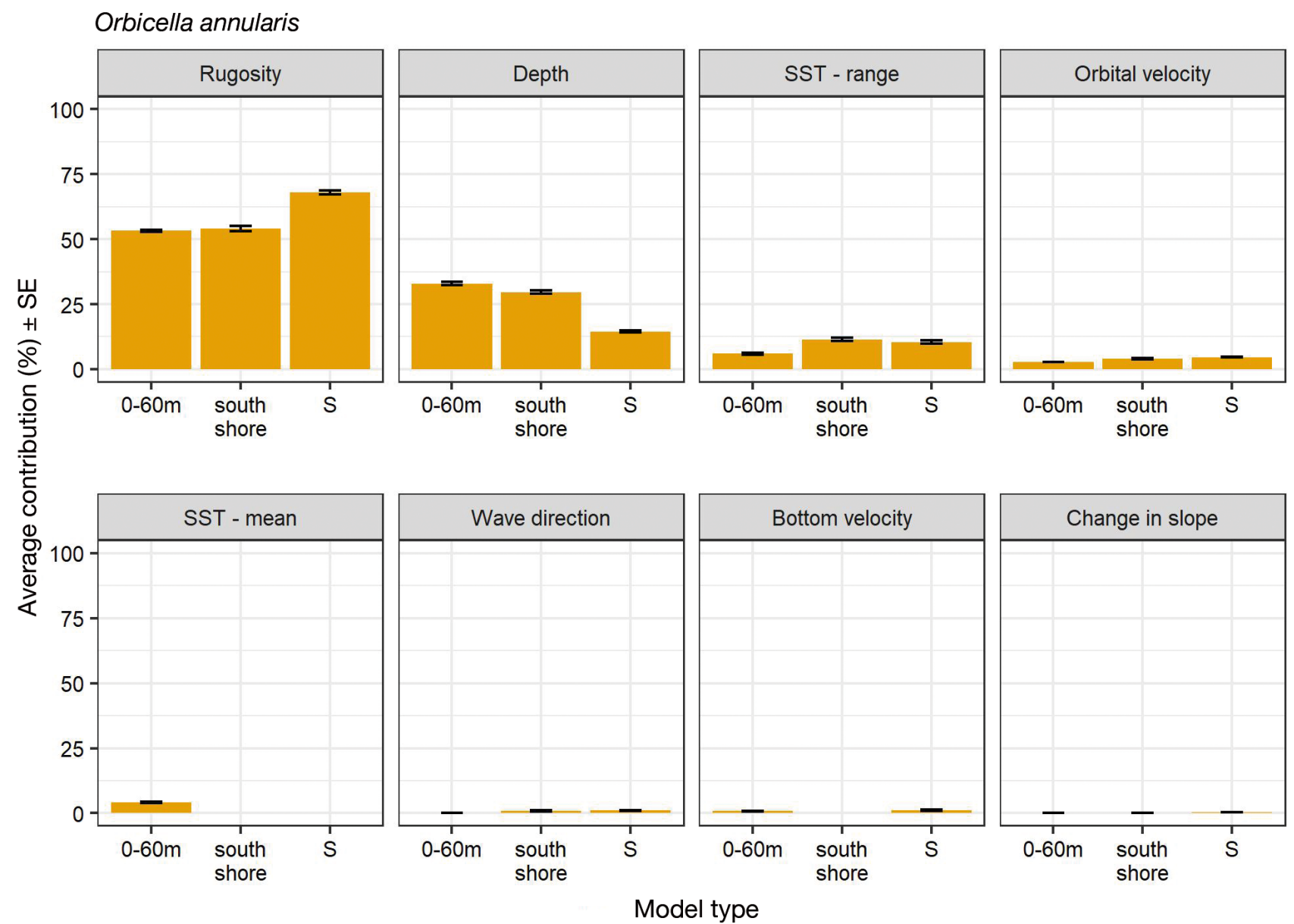

Fig. 5. Percent contribution of each variable for Orbicella annularis across the comparative model extents (0-60 m model, 0-60 m south shore only model, and the shallow only model [S]). Graphs are generally listed in order of which variables contributed most to the predictions. SST: sea surface temperature

at the lower SST range, but dropped off markedly above $27.7^{\circ} \mathrm{C}$. The orbital velocity response curve showed that high probability of occurrence peaked with very low orbital velocity, approaching 0.

\section{DISCUSSION}

The resulting spatial predictions indicated that unmonitored and unmanaged areas of Orbicella spp. are widespread in both shallow and mesophotic coral reef habitat along the eastern Puerto Rico Shelf. In particular, there is the potential for large areas of previously unidentified $O$. faveolata/O. franksi reef habitat at mesophotic depths. However, some of the model performance measures indicated areas of uncertainty and disagreement between spatial predictions and true occurrences. The abiotic variables that shaped these predicted distributions included rugosity, depth, wave exposure, and temperature.

\subsection{Abiotic contributions to Orbicella spp. distributions}

\subsubsection{Rugosity}

Rugosity was the strongest predictor for $O$. annularis and O. faveolata/O. franksi across several models, with increasing relief (rugosity $>1$ ) indicating an increased probability of occurrence. The response curves indicated that corals were excluded from flat areas. These flat areas are indicative of soft substrate, sediment, or depositional environments, and are not ideal habitat for coral settlement and growth. Corals could also be responding to high relief substrate in regards to settlement and subsequent survival. High relief substrate is a driver of coral distributions in Hawaii because antecedent reef structure (i.e. not created by recent reef building) creates ideal substrate (Jokiel et al. 2004), and similarly, antecedent reef buttresses also create ideal habitat for 


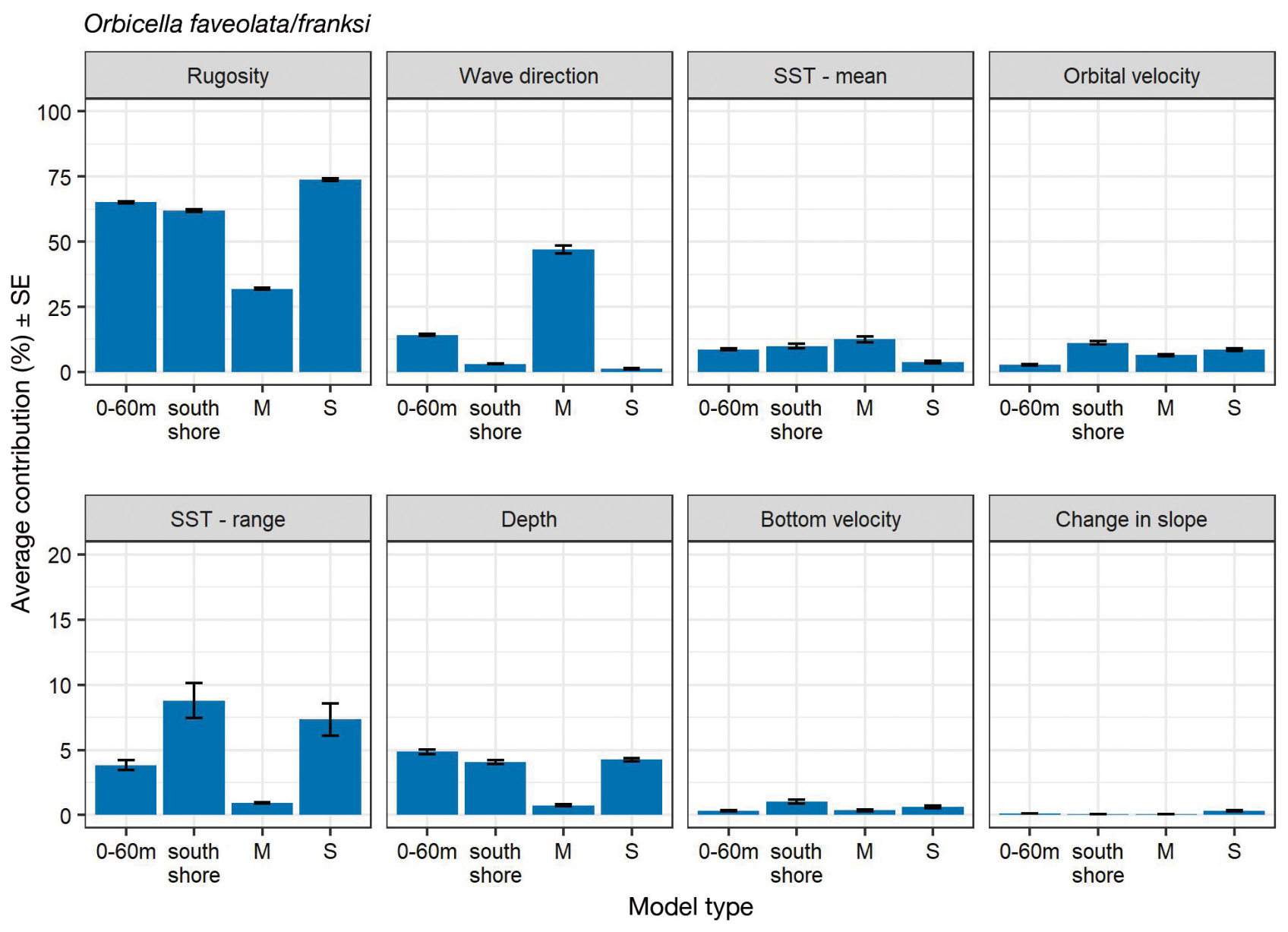

Fig. 6. As in Fig. 5, but for Orbicella faveolata/O. franksi (but includes the mesophotic only model [M]). Note differences in the $y$-axes for the variables, as they do not contribute equally to models

MCE development along a portion of the Puerto Rico Shelf (Sherman et al. 2010). In seafloor mapping studies, high rugosity values were indicative of hard coral occurrences in a shallow reef area of Puerto Rico (Prada et al. 2008) and in shallow and mesophotic coral reefs in Bonaire (Trembanis et al. 2017). Shallow coral occurrence was also predicted by both slope and rugosity in Hawaii (Franklin et al. 2013).

Spatial resolution is a key consideration for seafloor topography inclusion in SDMs (Pittman et al. 2009, Lecours et al. 2015). In our study, the rugosity measurement used in the models is more similar to a measurement of relief, and not a measurement of individual coral colonies that create the rugosity. Corals create rugosity (Alvarez-Filip et al. 2009, Graham \& Nash 2013), and Orbicella spp. are primary reef-building corals in shallow and mesophotic reef habitats (Weil \& Knowlton 1994, Newman et al. 2015). Orbicella spp. distributions were modeled at a $50 \mathrm{~m}$ resolution (i.e. much greater than the sizes of individual coral colonies), and the spatial scale sug- gests other types of rugose substrate, such as antecedent reef, are creating this ideal habitat. The resolution of the rugosity layer was derived from the $50 \mathrm{~m}$ bathymetric grid. The importance of rugosity in these models reflects the overall macro-structure and general topography of the reef, which could suggest that the antecedent reef structure is driving the model results. Shallow and mesophotic reefs are built upon drowned reefs submerged from sea level rise during the Pleistocene epoch (Lesser et al. 2018), and this antecedent reef could be providing the ideal topographic complexity and high relief habitat for Orbicella spp., similar to conditions in Hawaii (Jokiel et al. 2004) and Puerto Rico (Sherman et al. 2010).

Rugosity could also be acting as a proxy for the angle of available substrate, or slope, as they are positively correlated (dependent on spatial scale) (Pittman et al. 2009). Higher relief or more complex habitat is indicative of more angled surfaces. Although slope was tested in preliminary SDMs, it was not included in final model runs because the inclusion of 

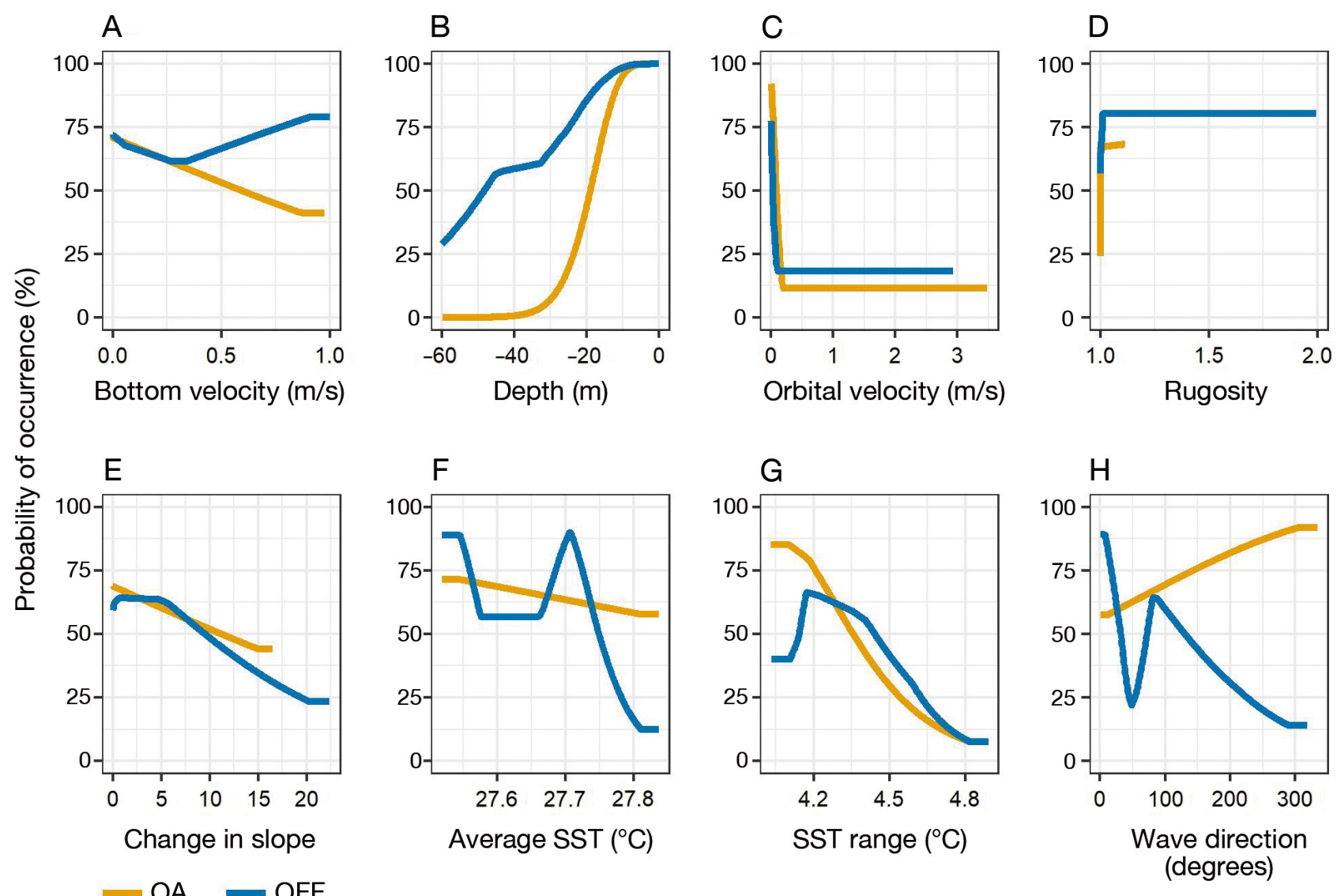

Fig. 7. Response curves for the 8 predictors that composed the best models for Orbicella annularis (OA) and O. faveolata/O. franksi (OFF) for the 0-60 m full model. The response curves for the single-variable model represent a MaxEnt model created using only that variable. The response curves show how each environmental variable affected the probability of occurrence when interacting with the other variables. SST: sea surface temperature

rugosity in the models produced higher AUC values. Seafloor slope affects sedimentation, which also structures MCEs (Sherman et al. 2016). High-relief areas favor the downslope transportation of sediment away from corals, improving coral development (Sherman et al. 2010). Slope and rugosity are also important for coral recruitment (Lesser et al. 2018). We suggest that rugosity is a strong predictor because it is a positive feedback loop for coral reef growth, i.e. rugosity encourages coral recruitment, which creates more rugosity. In shallow reef habitat, coral recruits prefer downward-facing substrate, and in deep areas, upper horizontal surfaces are preferred (Harborne et al. 2006). In studies using settlement tiles to observe coral recruitment, recruits also prefer rugose texture and refuges (Edmunds et al. 2014), although our models did not pick up on such fine-scale rugose features. The preference for more complex habitat reflects the preference of a coral for low light levels, low sedimentation rates, and protec- tion from competition and predation (van Woesik et al. 2014). Areas without relief or topographic complexity can limit coral recruitment due to lack of shelter, excessive algal growth, and the presence of sediment (Edwards \& Clark 1999). Rugose surfaces also lead to 'sticky water,' an oceanographic process where areas of high reef density are poorly flushed because the prevailing currents are directed away from these regions, leading to high levels of natal recruitment at well-developed reefs (Andutta et al. 2012).

\subsubsection{Wave direction}

Wave direction was a strong predictor of $O$. faveolata/O. franksi in the shallow and mesophotic models that included the north shelf habitats. This likely represents the strong spatial structuring of mean wave climate between the north and south shelves of the 
northern USVI. The north shelf is exposed to the Atlantic swell and sees a dominant wave climate from the northeast $\left(45^{\circ}\right)$, whereas the south shelf is sheltered from the Atlantic swell and has a wave climate dominated by regional trade winds from the east $\left(90^{\circ}\right)$. These dominant wave directions correspond to the low and high probability occurrence predictions in the models for O. faveolata/O. franksi. The wave direction importance in the models diminishes when the north is removed; thus, in the northinclusive model, the wave climates are likely separating the low occurrence mesophotic orbicellid areas of the north with the high occurrence mesophotic orbicellid areas of the south (Fig. 1; Smith et al. 2019). This does not mean that wave climate is contributing to the distribution of orbicellids in the north and south, as there might be other ecological reasons that orbicellids are rare in the north that are not accounted for in the modeling. Growth rates of $O$. franksi are similar at the same depths on the north and south shores around St. Thomas, suggesting recruitment or disturbance as a limiting factor for northern mesophotic populations (Groves et al. 2018). Wave climate and high swell events may cause chronic sediment resuspension or low-frequency mechanical disturbance that causes a low abundance of orbicellids on the mesophotic north shelf (Groves 2016). If shown, then wave direction could indicate a swell regime associated with disturbance and/or stress in mesophotic orbicellids of the northeastern Caribbean.

Wave direction could also be a proxy for food availability. Species-specific changes from autotrophy to heterotrophy occur from shallow to mesophotic depths (Lesser et al. 2018). Montastraea cavernosa becomes more heterotrophic at mesophotic depths, relying more on zooplankton and inorganic nutrients (Lesser et al. 2010). Potential food sources are transported onto the reef through upwelling or other sources. There is evidence from the Indo-Pacific to suggest that deep upwelling and wave direction drive food availability, which further drives coral trophic zonation (Williams et al. 2018, Radice et al. 2019).

\subsubsection{Temperature}

SST was also a contributing abiotic variable across all model extents. Generally, the response curves showed a pattern of decreased probability of occurrence with increasing temperatures or more variable temperature ranges. These environmental variable preferences are in close agreement with the findings of Castillo \& Helmuth (2005), who reported that $O$. annularis did not respond well physiologically to acute changes in temperature, and tended to prefer cooler waters in shallower areas. The SST range predictor did not capture acute changes in temperature, because it was averaged across several years; however, the model results provided insight into the habitat preferences for $O$. annularis based on low variability in temperature fluctuations. Changes in temperature over long periods of time have also contributed to the decline of $O$. annularis cover in Florida and the Caribbean (St. John, USVI, Edmunds \& Elahi 2007; Florida Keys, Ruzicka et al. 2013), providing further evidence that $O$. annularis requires a certain ideal temperature range to thrive. Temperature plays a key role in differentiating between shallow and mesophotic reef habitats as well, and is a limiting factor in determining the lower depth limits of MCEs (Bongaerts et al. 2015). MCEs are cooler than shallow reefs (Lesser et al. 2009, Smith et al. 2016b, Lesser et al. 2018) most likely from internal oceanographic processes (Bak et al. 2005). Smith et al. (2016b) identified that benthic temperatures in Orbicella spp. mesophotic sites were cooler than shallow coral reefs in the USVI specifically, which could explain the difference in temperature contributions for the shallow and mesophotic only models. Orbicella spp. at mesophotic depths are more sensitive to elevated temperatures, and have likely acclimated to temperatures at these depths, thus making cooler temperatures ideal for Orbicella spp. (Smith et al. 2016b). We used SST data from 2011-2017 to closely match the data collected for presences of Orbicella spp., which is common in the coral modeling literature (see Georgian et al. 2014, Costa et al. 2015, Chen et al. 2020). These current Orbicella spp. presences may be driven by current temperature conditions, but increases in temperature due to climate change are already causing, and will continue to cause, negative impacts to coral populations.

Benthic temperature data were not used in the MaxEnt models because they were not available for the entire model extent. Winship et al. (2020) recommended using in situ temperature data to create an interpolated temperature grid at depth for deep coral SDMs. While some in situ temperature data were available for the study region, there were not enough data to accurately create a bottom temperature grid. The use of SST could be a proxy for benthic temperatures instead. Costa et al. (2015) identified that SST in Hawaii was a proxy for benthic temperature at mesophotic depths, and similar results were seen in 
other parts of the Pacific (Kahng et al. 2012). In the Caribbean, comparisons between satellite-measured temperature and in situ temperature measurements have only been documented within the first $20 \mathrm{~m}$ of water (Castillo \& Lima 2010, Neal et al. 2014, Gomez et al. 2020). For the purposes of this study, correlations with benthic and satellite-measured temperatures would potentially make SST an ideal predictor to use in modeling species distributions at shallower depths. It is unknown if this would work similarly at mesophotic depths in the Caribbean and is something to consider for future study.

\subsection{Model error and uncertainty}

The distributions of both coral groups are potentially inaccurate in some areas, given the high MAE values. The MAE values were high when calculated separately for the presences and absences (rather than combined) for O. faveolata/O. franksi. High MAE for presences is indicative of underpredictions from the model, whereas high MAE for absences is indicative of overprediction. The high MAE exhibited may be due to missing or inaccurate environmental predictors such as backscatter and light-attenuation grids (Kahng et al. 2019, Tamir et al. 2019). Environmental data are sparse for marine environments compared to terrestrial environments (Robinson et al. 2011). Most datasets are available for the surface and subsurface levels, and rarely for deeper depths (Lecours et al. 2015). Several predictors used in these SDMs were surface values at coarse resolutions $(1 \mathrm{~km})$, and may not be indicative of coral distributions at mesophotic depths. Several of the predictors were also resampled from coarser $(1 \mathrm{~km})$ to finer resolutions $(50 \mathrm{~m})$, further introducing error.

High-resolution multibeam or LiDAR provides bathymetry and rugosity data that are key habitat descriptors to include in marine SDMs (Valavanis et al. 2008, Pittman et al. 2009). Acoustic backscatter data differentiate between hard- and softbottom habitats (Anderson et al. 2008), but were not available for the entirety of the region. However, combining backscatter data from different multibeam datasets could prove problematic due to the subjective way backscatter is processed. It is important to differentiate between hard- and softbottom, but not all hardbottom habitat is ideal for coral settlement and growth. The upper mesophotic zone along the southern insular shelf contains a variety of hardbottom habitat including horizontal banks, steep slopes, and walls. Orbicella spp. occur on horizontal banks, whereas Agaricia spp. are common on steep slopes and walls. The upper mesophotic zone also supports large areas of softbottom habitat, which is largely composed of rhodolith beds. These beds contain small stony coral patches, including the sparse occurrence of orbicellid colonies (Smith et al. 2019). Parsing out different kinds of ideal habitat for orbicellids would be advantageous in future modeling efforts and would also contribute greatly to a regionwide benthic habitat map. High-quality benthic habitat maps cover most of the modeling area (see Kendall et al. 2001, Kågesten et al. 2015, Costa et al. 2017); however, a benthic habitat map encompassing the entire model extent has not been created due to lack of multibeam and acoustic backscatter data for parts of the northeast shore of the northern USVI.

Another source of error and uncertainty in our models comes from the spatially autocorrelated Orbicella spp. presences, which can greatly bias model results (Dormann et al. 2007). Spatial autocorrelation of the data is most likely due to the heterogeneous nature of the compiled datasets, using data from multiple different sources with varying survey designs as outlined in Section 2.2. Future modeling efforts could utilize the methods of Georgian et al. (2019), who calculated a residual autocovariate (RAC) variable for each taxonomic group they modeled. The RAC method derives a term representing the spatial autocorrelation present in the residuals of a preliminary model. This term is then added as an explanatory variable in the subsequent models and reduces modeling error.

\subsection{Conclusion}

The results of this study provide predicted distributions of Orbicella spp. and mesophotic reef locations that are located along the eastern Puerto Rico Shelf on a broad scale under current environmental conditions. Shallow and mesophotic reef ecosystems have the potential for large areas of unexplored, unmonitored, and unmanaged areas of orbicellid-dominated reef habitat. The spatial predictive maps now need to be ground-truthed, in conjunction with uncertainty maps, to further characterize mesophotic orbicellid communities, which would lead to more effective monitoring of these declining species. The SDMs could be refined, with the collection of environmental data at higher spatial resolutions, larger spatial extents, the addition of new environmental predictors, and through the use of more refined modeling techniques (i.e. presence/absence or density model- 
ing). Multibeam, acoustic backscatter, benthic habitat maps, and light attenuation are missing for some of the region, and collection of these data will greatly refine the orbicellid models. Gridded benthic temperature data are needed for the entire modeled region to assess whether satellite-derived temperature is correlated with benthic temperature. This in turn could provide more information about temperature as a driver in orbicellid distributions. Refined models would theoretically lead to more accurate spatial predictive maps, which would further lead to a better understanding of these unexplored orbicelliddominated reefs.

Acknowledgements. We thank Dr. Richard Appeldoorn, Dr. Marilyn Brandt, and Elizabeth Brown for providing orbicellid survey data; Erik Ebert for assistance in bathymetry acquisition; Dr. Sonaljit Mukherjee for help in preparing the bottom velocity data; Bryan Costa and Dr. Yi-Hsiu Chen for help with the MaxEnt models; and Lora Johansen for providing feedback on earlier drafts. We also thank Tomma Barnes, Jennifer Moore, and Dr. Arliss Winship for providing helpful comments that greatly improved the manuscript. Thank you to the 3 anonymous reviewers for their valuable feedback. This work was funded by the Virgin Islands Experimental Program to Stimulate Competitive Research (NSF 0814417), the National Science Foundation Scholarship in Science, Technology, Engineering, and Mathematics awarded to the University of the Virgin Islands (NSF 1356632), and by the NOAA Fisheries Science and Technology Toolbox. This is contribution no. 228 from the Center for Marine and Environmental Studies, University of the Virgin Islands. The scientific results and conclusions, as well as any views or opinions expressed herein, are those of the authors and do not necessarily reflect the views of NOAA or the Department of Commerce.

\section{LITERATURE CITED}

Alvarez-Filip L, Dulvy NK, Gill JA, Côté IM, Watkinson AR (2009) Flattening of Caribbean coral reefs: region-wide declines in architectural complexity. Proc R Soc B 276:3019-3025

Anderson JT, Van Holliday D, Kloser R, Reid DG, Simard Y (2008) Acoustic seabed classification: current practice and future directions. ICES J Mar Sci 65:1004-1011

Andutta FP, Kingsford MJ, Wolanski E (2012) 'Sticky water' enables the retention of larvae in a reef mosaic. Estuar Coast Shelf Sci 101:54-63

*Anselmi-Molina CM, Canals M, Morell J, Gonzalez J, Capella J, Mercado A (2012) Development of an operational nearshore wave forecast system for Puerto Rico and the US Virgin Islands. J Coast Res 284:1049-1056

Armstrong RA, Singh H, Torres J, Nemeth RS and others (2006) Characterizing the deep insular shelf coral reef habitat of the Hind Bank marine conservation district (US Virgin Islands) using the Seabed autonomous underwater vehicle. Cont Shelf Res 26:194-205

Aronson RB, Precht WF (2001) White-band disease and the changing face of Caribbean coral reefs. In: Porter JW (ed) The ecology and etiology of newly emerging marine diseases. Springer Netherlands, Dordrecht, p 25-38

Bak RPM, Nieuwland G, Meesters EH (2005) Coral reef crisis in deep and shallow reefs: 30 years of constancy and change in reefs of Curacao and Bonaire. Coral Reefs 24:475-479

* Barry S, Elith J (2006) Error and uncertainty in habitat models. J Appl Ecol 43:413-423

*Bongaerts P, Frade PR, Hay KB, Englebert N and others (2015) Deep down on a Caribbean reef: lower mesophotic depths harbor a specialized coral-endosymbiont community. Sci Rep 5:7652

*Booij N, Ris RC, Holthuijsen LH (1999) A third-generation wave model for coastal regions: 1 . Model description and validation. J Geophys Res Oceans 104:7649-7666

* Bridge T, Beaman R, Done T, Webster J (2012) Predicting the location and spatial extent of submerged coral reef habitat in the Great Barrier Reef World Heritage Area, Australia. PLOS ONE 7:e48203

Burnham KP, Anderson DR (2002) Model selection and multimodel inference: a practical information-theoretic approach, $2^{\text {nd }}$ edn. Springer, New York, NY

Canals M, Morell J, Corredor JE, Leonardi S (2012) Expanding the Caribbean Coastal Ocean Observing System into the nearshore region. 2012 Oceans, Hampton Roads, VA, USA, p 1-4

* Castillo KD, Helmuth BST (2005) Influence of thermal history on the response of Montastraea annularis to shortterm temperature exposure. Mar Biol 148:261-270

* Castillo KD, Lima FP (2010) Comparison of in situ and satellite-derived (MODIS-Aqua/Terra) methods for assessing temperatures on coral reefs: subtidal and SSTs on coral reefs. Limnol Oceanogr Methods 8:107-117

Chen YH, Shertzer KW, Viehman TS (2020) Spatio-temporal dynamics of the threatened elkhorn coral Acropora palmata: implications for conservation. Divers Distrib 26: 1582-1597

Cherubin LM, Nemeth RS, Idrisi N (2011) Flow and transport characteristics at an Epinephelus guttatus (red hind grouper) spawning aggregation site in St. Thomas (US Virgin Islands). Ecol Model 222:3132-3148

* Chollett I, Mumby PJ (2012) Predicting the distribution of Montastraea reefs using wave exposure. Coral Reefs 31:493-503

Costa B, Kendall MS, Parrish FA, Rooney J and others (2015) Identifying suitable locations for mesophotic hard corals offshore of Maui, Hawai'i. PLOS ONE 10:e0130285

Costa B, Kracker L, Battista T, Sautter W and others (2017) Benthic habitat maps for the insular shelf South of St. Thomas and St. John. NOAA Tech Memo NOS NCCOS 241

Done TJ (1983) Coral zonation, its nature and significance. In: Barnes DJ, Clouston B (eds) Perspectives on coral reefs. Australian Institute of Marine Sciences, Townsville, p 107-147

* Dormann CF, McPherson JM, Araújo MB, Bivand R and others (2007) Methods to account for spatial autocorrelation in the analysis of species distributional data: a review. Ecography 30:609-628

Edmunds PJ (2015) A quarter-century demographic analysis of the Caribbean coral, Orbicella annularis, and projections of population size over the next century. Limnol Oceanogr 60:840-855

Edmunds PJ, Elahi R (2007) The demographics of a 15-year decline in cover of the Caribbean reef coral Montastraea 
annularis. Ecol Monogr 77:3-18

Edmunds PJ, Nozawa Y, Villanueva RD (2014) Refuges modulate coral recruitment in the Caribbean and the Pacific. J Exp Mar Biol Ecol 454:78-84

Edwards AJ, Clark S (1999) Coral transplantation: a useful management tool or misguided meddling? Mar Pollut Bull 37:474-487

Elith J, Leathwick JR (2009) Species distribution models: ecological explanation and prediction across space and time. Annu Rev Ecol Evol Syst 40:677-697

Elith J, Phillips SJ, Hastie T, Dudík M, Chee YE, Yates CJ (2011) A statistical explanation of MaxEnt for ecologists. Divers Distrib 17:43-57

*Engler R, Guisan A, Rechsteiner L (2004) An improved approach for predicting the distribution of rare and endangered species from occurrence and pseudoabsence data. J Appl Ecol 41:263-274

Franklin J, Miller JA (2009) Mapping species distributions: spatial inference and prediction. Cambridge University Press, Cambridge

Franklin EC, Jokiel PL, Donahue MJ (2013) Predictive modeling of coral distribution and abundance in the Hawaiian Islands. Mar Ecol Prog Ser 481:121-132

Georgian SE, Shedd W, Cordes EE (2014) High-resolution ecological niche modelling of the cold-water coral Lophelia pertusa in the Gulf of Mexico. Mar Ecol Prog Ser 506:145-161

*Georgian SE, Anderson OF, Rowden AA (2019) Ensemble habitat suitability modeling of vulnerable marine ecosystem indicator taxa to inform deep-sea fisheries management in the South Pacific Ocean. Fish Res 211:256-274

* Godown ME, Peterson AT (2000) Preliminary distributional analysis of US endangered bird species. Biodivers Conserv 9:1313-1322

Gomez AM, McDonald KC, Shein K, DeVries S, Armstrong RA, Hernandez WJ, Carlo M (2020) Comparison of satellite-based sea surface temperature to in situ observations surrounding coral reefs in La Parguera, Puerto Rico. J Mar Sci Eng 8:453

Goreau TF, Wells JW (1967) The shallow-water Scleractinia of Jamaica: revised list of species and their vertical distribution range. Bull Mar Sci 17:442-453

Graham NAJ, Nash KL (2013) The importance of structural complexity in coral reef ecosystems. Coral Reefs 32: 315-326

Groves SH (2016) Physical drivers of community structure and growth among mesophotic coral reef ecosystems surrounding St. Thomas, US Virgin Islands. MSc thesis, University of the Virgin Islands, St. Thomas

* Groves SH, Holstein DM, Enochs IC, Kolodzeij G, Manzello DP, Brandt ME, Smith TB (2018) Growth rates of Porites astreoides and Orbicella franksi in mesophotic habitats surrounding St. Thomas, US Virgin Islands. Coral Reefs 37:345-354

* Guisan A, Zimmermann NE (2000) Predictive habitat distribution models in ecology. Ecol Model 135:147-186

Guisan A, Tingley R, Baumgartner JB, Naujokaitis-Lewis I and others (2013) Predicting species distributions for conservation decisions. Ecol Lett 16:1424-1435

Harborne AR, Mumby PJ, Micheli F, Perry CT, Dahlgren CP, Holmes KE, Brumbaugh DR (2006) The functional value of Caribbean coral reef, seagrass and mangrove habitats to ecosystem processes. Adv Marine Biol 50:57-189

Herzlieb S, Kadison E, Blondeau J, Nemeth RS (2006) Comparative assessment of coral reef systems located along the insular platform south of St. Thomas, US Virgin Islands and the relative effects of natural and human impacts. Proc 10th Int Coral Reef Symp 4:1144-1151

* Hinderstein LM, Marr JCA, Martinez FA, Dowgiallo MJ and others (2010) Theme section on 'Mesophotic Coral Ecosystems: Characterization, Ecology, and Management.' Coral Reefs 29:247-251

Hosmer DW, Lemeshow S, Sturdivant RX (2013) Applied logistic regression, $3^{\text {rd }}$ edn. John Wiley \& Sons, Hoboken, NJ

Jackson J, Donovan M, Cramer K, Lam V (eds) (2014) Status and trends of Caribbean coral reefs: 1970-2012. Global Coral Reef Monitoring Network, IUCN, Gland

Jenness JS (2004) Calculating landscape surface area from digital elevation models. Wildl Soc Bull 32:829-839

Jenness J (2013) DEM Surface Tools for ArcGIS 10. http:// www.jennessent.com/arcgis/surface_area.htm

Jokiel PL, Paul L, Brown EK, Friedlander A, Rodgers SK, Smith WR (2004) Hawai'i coral reef assessment and monitoring program: spatial patterns and temporal dynamics in reef coral communities. Pac Sci 58:159-174

Jueterbock A, Smolina I, Coyer JA, Hoarau G (2016) The fate of the Arctic seaweed Fucus distichus under climate change: an ecological niche modeling approach. Ecol Evol 6:1712-1724

Kadison E, Brandt M, Nemeth R, Martens J, Blondeau J, Smith T (2017) Abundance of commercially important reef fish indicates different levels of over-exploitation across shelves of the US Virgin Islands. PLOS ONE 12:e0180063

Kågesten G, Sautter W, Edwards KA, Costa B, Kracker LM, Battista TA (2015) Shallow-water benthic habitats of Northeast Puerto Rico and Culebra Island. NOAA Tech Memo NOS NCCOS 200

Kahng SE, Wagner D, Lantz C, Vetter O, Gove J, Merrifield M (2012) Temperature related depth limits of warmwater corals. Proc 12th Int Coral Reef Symp: 9C

Kahng S, Akkaynak D, Shlesinger T, Hochberg E, Wiedenmann J, Tamir R (2019) Light, temperature, photosynthesis, heterotrophy, and the lower depth limits of mesophotic coral ecosystems. In: Loya Y, Puglise K, Bridge T (eds) Mesophotic coral ecosystems. Coral Reefs of the World, Vol 12. Springer, Cham, p 801-828

Kendall MS, Kruer CR, Buja KR, Christensen JD, Finkbeiner M, Warner RA, Monaco ME (2001) Methods used to map the benthic habitats of Puerto Rico and the US Virgin Islands. NOAA Tech Memo NOS NCCOS 152

Kinlan BP, Poti M, Drohan AF, Packer DB, Dorfman DS, Nizinski MS (2020) Predictive modeling of suitable habitat for deep-sea corals offshore the Northeast United States. Deep Sea Res I 158:103229

* Lecours V, Devillers R, Schneider DC, Lucieer VL, Brown CJ, Edinger EN (2015) Spatial scale and geographic context in benthic habitat mapping: review and future directions. Mar Ecol Prog Ser 535:259-284

*Lesser MP, Slattery M, Leichter JJ (2009) Ecology of mesophotic coral reefs. J Exp Mar Biol Ecol 375:1-8

* Lesser MP, Slattery M, Stat M, Ojimi M, Gates RD, Grottoli A (2010) Photoacclimatization by the coral Montastraea cavernosa in the mesophotic zone: light, food, and genetics. Ecology 91:990-1003

K Lesser MP, Slattery M, Mobley CD (2018) Biodiversity and functional ecology of mesophotic coral reefs. Annu Rev Ecol Evol Syst 49:49-71

Liu C, White M, Newell G (2009) Measuring the accuracy of 
species distribution models: a review. $18^{\text {th }}$ World IMACS / MODSIM Congress, Cairns, Australia 13-17 July 2009, p 4241-4247

Liu C, White M, Newell G (2013) Selecting thresholds for the prediction of species occurrence with presence-only data. J Biogeogr 40:778-789

Liu C, Newell G, White M (2016) On the selection of thresholds for predicting species occurrence with presenceonly data. Ecol Evol 6:337-348

Lobo JM, Jiménez-Valverde A, Real R (2008) AUC: a misleading measure of the performance of predictive distribution models. Glob Ecol Biogeogr 17:145-151

Menza C, Kendall M, Hile S (2008) The deeper we go the less we know. Rev Biol Trop 56:11-24

Merow C, Smith MJ, Silander JA (2013) A practical guide to MaxEnt for modeling species' distributions: what it does, and why inputs and settings matter. Ecography 36: 1058-1069

* NCCOS (National Centers for Coastal Ocean Science) (2016) National Coral Reef Monitoring Program: assessment of coral reef benthic communities in the US Virgin Islands. NOAA National Centers for Environmental Information (Collection). https://www.ncei.noaa.gov/access/ metadata/landing-page/bin/iso?id=gov.noaa.nodc:NCRMPBenthic-USVI

NCCOS, SEFSC (Southeast Fisheries Science Center) (2018) National Coral Reef Monitoring Program: assessment of coral reef benthic communities in Puerto Rico. NOAA National Centers for Environmental Information (Collection). https://www.ncei.noaa.gov/access/metadata/landing-page/ bin/iso?id=gov.noaa.nodc:NCRMP-Benthic-PR

Neal BP, Condit C, Liu G, dos Santos S, Kahru M, Mitchell BG, Kline DI (2014) When depth is no refuge: cumulative thermal stress increases with depth in Bocas del Toro, Panama. Coral Reefs 33:193-205

Newman SP, Meesters EH, Dryden CS, Williams SM, Sanchez C, Mumby PJ, Polunin NVC (2015) Reef flattening effects on total richness and species responses in the Caribbean. J Anim Ecol 84:1678-1689

* Pandolfi JM, Budd AF (2008) Morphology and ecological zonation of Caribbean reef corals: the Montastraea 'annularis' species complex. Mar Ecol Prog Ser 369:89-102

Pandolfi JM, Bradbury RH, Sala E, Hughes TP and others (2003) Global trajectories of the long-term decline of coral reef ecosystems. Science 301:955-958

Phillips SJ, Dudík M, Schapire RE (2004) A maximum entropy approach to species distribution modeling. In: Proc $21^{\text {st }}$ Int Conf Machine Learning - ICML '04. ACM Press, Banff, p 655-662

*Phillips SJ, Anderson RP, Schapire RE (2006) Maximum entropy modeling of species geographic distributions. Ecol Model 190:231-259

* Phillips SJ, Anderson RP, Dudík M, Schapire RE, Blair ME (2017) Opening the black box: an open-source release of Maxent. Ecography 40:887-893

* Pittman SJ, Costa BM, Battista TA (2009) Using lidar bathymetry and boosted regression trees to predict the diversity and abundance of fish and corals. J Coast Res 10053:27-38

* Prada MC, Appeldoorn RS, Rivera JA (2008) Improving coral reef habitat mapping of the Puerto Rico insular shelf using side scan sonar. Mar Geod 31:49-73

R Core Team (2017) R: a language and environment for statistical computing. R Foundation for Statistical Computing, Vienna
Radice VZ, Hoegh-Guldberg O, Fry B, Fox MD, Dove SG (2019) Upwelling as the major source of nitrogen for shallow and deep reef-building corals across an oceanic atoll system. Funct Ecol 33:1120-1134

Reed J (1985) Deepest distribution of Atlantic hermatypic corals discovered in the Bahamas. Proc 5th Int Coral Reef Congr 6:249-254

Renner IW, Warton DI (2013) Equivalence of MAXENT and Poisson point process models for species distribution modeling in ecology. Biometrics 69:274-281

Robinson LM, Elith J, Hobday AJ, Pearson RG, Kendall BE, Possingham HP, Richardson AJ (2011) Pushing the limits in marine species distribution modelling: Lessons from the land present challenges and opportunities. Glob Ecol Biogeogr 20:789-802

Ruzicka RR, Colella MA, Porter JW, Morrison JM and others (2013) Temporal changes in benthic assemblages on Florida Keys reefs 11 years after the 1997/1998 El Niño. Mar Ecol Prog Ser 489:125-141

* Sheppard CRC (1982) Coral populations on reef slopes and their major controls. Mar Ecol Prog Ser 7:83-115

* Sherman C, Nemeth M, Ruíz H, Bejarano I and others (2010) Geomorphology and benthic cover of mesophotic coral ecosystems of the upper insular slope of southwest Puerto Rico. Coral Reefs 29:347-360

* Sherman C, Schmidt W, Appeldoorn R, Hutchinson Y and others (2016) Sediment dynamics and their potential influence on insular-slope mesophotic coral ecosystems. Cont Shelf Res 129:1-9

* Silva M, MacDonald IR (2017) Habitat suitability modeling for mesophotic coral in the northeastern Gulf of Mexico. Mar Ecol Prog Ser 583:121-136

* Smith TB, Nemeth RS, Blondeau J, Calnan JM, Kadison E, Herzlieb S (2008) Assessing coral reef health across onshore to offshore stress gradients in the US Virgin Islands. Mar Pollut Bull 56:1983-1991

* Smith TB, Blondeau J, Nemeth RS, Pittman SJ, Calnan JM, Kadison E, Gass J (2010) Benthic structure and cryptic mortality in a Caribbean mesophotic coral reef bank system, the Hind Bank Marine Conservation District, US Virgin Islands. Coral Reefs 29:289-308

* Smith TB, Ennis R, Kadison E, Weinstein D, Jossart J, Gyory J, Henderson L (2015) The United States Virgin Islands Territorial Coral Reef Monitoring Program. Year 15 Annual Report

Smith TB, Brandtneris VW, Canals M, Brandt ME and others (2016a) Potential structuring forces on a shelf edge upper mesophotic coral ecosystem in the US Virgin Islands. Front Mar Sci 3:115

* Smith TB, Gyory J, Brandt ME, Miller WJ, Jossart J, Nemeth RS (2016b) Caribbean mesophotic coral ecosystems are unlikely climate change refugia. Glob Change Biol 22: 2756-2765

Smith TB, Brandt ME, Brandtneris VW, Ennis RS and others (2019) The United States Virgin Islands. In: Loya Y, Puglise KA, Bridge TCL (eds) Mesophotic coral ecosystems. Springer International Publishing, Cham, p 131-147

* Szmant AM, Weil E, Miller MW, Colón DE (1997) Hybridization within the species complex of the scleractinan [sic] coral Montastraea annularis. Mar Biol 129:561-572

Tamir R, Eyal G, Kramer N, Laverick JH, Loya Y (2019) Light environment drives the shallow-to-mesophotic coral community transition. Ecosphere 10:e02839

* Trembanis AC, Forrest AL, Keller BM, Patterson MR (2017) Mesophotic coral ecosystems: a geoacoustically 
derived proxy for habitat and relative diversity for the leeward shelf of Bonaire, Dutch Caribbean. Front Mar Sci $4: 51$

Valavanis VD, Pierce GJ, Zuur AF, Palialexis A, Saveliev A, Katara I, Wang J (2008) Modelling of essential fish habitat based on remote sensing, spatial analysis and GIS. Hydrobiologia 612:5-20

Van Horn B (2002) Approaches to habitat modelling: the tensions between pattern and process and between specificity and generality. In: Scott J, Heglund P, Morrison M, Haufler J, Raphael M, Wall W, Samson F (eds) Predicting species occurrences: issues of accuracy and scale. Island Press, Covelo, CA, p 63-72

van Woesik R, Scott WJ, Aronson RB (2014) Lost opportunities: Coral recruitment does not translate to reef recovery in the Florida Keys. Mar Pollut Bull 88:110-117

Weil E, Knowlton N (1994) A multi-character analysis of the Caribbean coral Montastraea annularis (Ellis and

Editorial responsibility: Peter Edmunds,

Northridge, California, USA

Reviewed by: F. Sinniger and 2 anonymous referees
Solander, 1786) and its two sibling species, M. faveolata (Ellis and Solander, 1786) and M. franksi (Gregory, 1895). Bull Mar Sci 55:151-175

Wiberg PL, Sherwood CR (2008) Calculating wave-generated bottom orbital velocities from surface-wave parameters. Comput Geosci 34:1243-1262

Williams GJ, Sandin SA, Zgliczynski BJ, Fox MD and others (2018) Biophysical drivers of coral trophic depth zonation. Mar Biol 165:60

*Wilson MFJ, O'Connell B, Brown C, Guinan JC, Grehan AJ (2007) Multiscale terrain analysis of multibeam bathymetry data for habitat mapping on the continental slope. Mar Geod 30:3-35

Winship AJ, Thorson JT, Clarke ME, Coleman HM and others (2020) Good practices for species distribution modeling of deep-sea corals and sponges for resource management: data collection, analysis, validation, and communication. Front Mar Sci 7:303

Submitted: August 24, 2020

Accepted: March 15, 2021

Proofs received from author(s): June 7, 2021 